\title{
2 Archiving cultural capital
}

I would enshrine the image of the past

For future restoration ${ }^{1}$

There is a clear pattern as to how the manuscript texts from the Warring States period relate to the mainstays of Zhōu culture. The texts normally present stable pairings, comprised of Shī (Songs) and Shū (Documents) as one pair; Lǐ (rites/rituals) and Yuè (music) as another; Yì (Changes) and Chūnqiū (Annals) as a third. In addition, rites and music are sometimes also paired with other cultural institutions such as law and punishments.

The two pairs, Songs and Documents on the one hand and Changes and Annals on the other, are conspiciously different. Unlike rituals and music, and unlike law and punishments, it seems they represent categories which more plainly stand on their own in the eyes of their contemporaneous beholder. Although to some extent they are all described as cultural practices, Songs and Documents, and Changes and Annals seem to come with at least some textual representation (and expectation of the same), lending stability to their conceptualisation as groups. This conclusion is supported by further palaeographical evidence. ${ }^{2}$ Songs and Documents in particular stand out, suggesting they had a more dominant status at the time.

This picture is given further support by "Zīyì", a highly schematic contextdependent text from the Warring States period. It repeatedly weaves phrases from the Shì and Shū into a themed texture of its own making, while other foundational sources-except sayings from the Master himself-are prominently absent from its manuscript representations.

Looking at "Zīyì" is therefore instructive. While it confirms the special status of the Shi and the Shū, it also complicates our picture of the foundational texts and their users at the time, casting light, in a limited way, on how they were used by the text communities behind the making of "Zìyi".

1 William Wordsworth, Prelude 1805, XI, v. 342-343.

2 Shaughnessy 2014; Huáng Dékuān 2017; Kern and Meyer 2017a.

ว Open Access. ( 2021 Dirk Meyer/JAS, published by De Gruyter. ((c))BY-NC-ND This work is licensed under the Creative Commons Attribution-NonCommercial-NoDerivatives 4.0 License. https://doi.org/10.1515/9783110708530-003 


\section{1 "Zīyī"}

In general, transmitted texts from the Warring States contain just a few intertextual correspondences with Shū, and such correspondences should be viewed with some caution because of the growing belief in text stability and text cohesion during the empires. Transmitted pre-Qin texts is a contradiction in terms, since the texts were subject to later rewriting. They do therefore not serve as a reliable point of reference without further material support. "Zīyî" is, however, ideal as a point of reference because it comes in different recensions, excavated and transmitted alike. Moreover, the importance of "Zìyì" further lies in its structured, and explicit, reference to the Shì and Shū for much of the work. Unlike argument-based texts written in continuous mode, "Zīyì" is organised in disconnected 'units of thought'. ${ }^{3}$ The regular references to Shī and Shū in these units appear parallel to sayings referenced as ž yue 子曰, 'the Master says' (or 'the masters say), which frame the various units and mark them each as independent entities. This may look as follows:

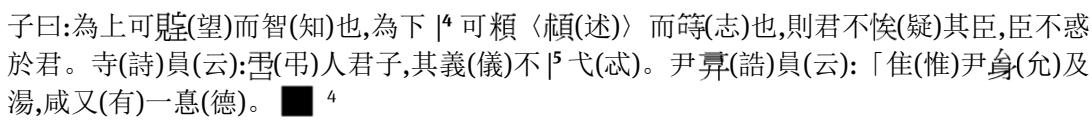

The Master said: 'When those on high can be looked up to and understood, and those below ${ }^{4} \mathrm{can}$ be [made to] follow and taken note of, then lords will not hold in doubt their ministers, and ministers will not be confused about their rulers'.

Songs say: 'The good and noble person, ${ }^{5}$ their standards are not $\left.\right|^{5}$ ambiguous'.

Yĩn's admonitions proclaim: 'Truly [Yi] Yin and [King] Tang both had one single mind”.

As in this example, the various units are introduced by a statement put into the mouth of a, or more likely the master, traditionally understood as Confucius. These 'master sayings', ${ }^{6}$ as I wish to call them, are paired with references to at least one foundational text, Shī or Shū. For the most part, this is to Shī, consistently introduced as 'Songs say' [寺(詩)員(云)], but references to Shū are also

3 The term appeared first in Wagner 1999. Wagner's concept is not entirely unproblematic because it requires a definition of 'thought'. In this book I use unit of thought to denote a textual unit that puts forward one self-contained concern.

4 Guōdiàn "Zīyì”" unit 3 (L Ľiji 10): Slips 3/14-5/13. For the reconstruction of the text, see Shaughnessy 2006: 96-97; S. Cook 2012: 379-380.

5 Guided by the Máo recension, most commentators here read 费 as 淑. For a discussion as to why 吊 'good, fine' might work better, see Meyer and Schwartz 2021b.

6 My use of the term 'master saying' should not be taken as an equivalent to Denecke's 2010 "masters' literature", which I consider methodologically problematic because it studies heterogeneous pre-imperial traditions from the perspective of imperial catalogues. 
made with some regularity. The transmitted "Zīyī" moreover makes one reference to the Changes ( $Y \hat{\imath}$ 易) and to the Chūnqiū. ${ }^{7}$ Not so the manuscript texts.

In its transmitted form, “Zīyī” belongs to the imperial classic L Ľj i 禮記 (Record of Rites), a ritualist's miscellany that contains a variety of ritual 'prescriptions, definitions, and anecdotes', ${ }^{8}$ providing reflections on, and conceptualisations of, rites. Much of the rites recorded in the $L \check{i} j \grave{i}$, however, reflect imperial imagination rather than ancient realities.

Next to the transmitted recension in the Lijì "Zìyī" also comes in two manuscript representations - one was excavated from Guōdiàn; the other is part of the Shànghăi collection of Chǔ manuscripts, bought by the Shànghăi Museum in 1994 and published in volume 1 of the Shànghăi Manuscripts. The two manuscript texts are strikingly similar but differ substantially from the received text in structural terms. Ignoring for a moment that Shànghăi "Zīyī” is not so well preserved, ${ }^{9}$ the two manuscript texts have the same length, the same contents, and even share the sequence of their units of thought, both of which differ in the received recension. But not just the order of the units differs between manuscript texts and the received recension - even their internal makeup is not consistent with the received text. The individual units are also much shorter in the manuscript texts. Given the high structural cohesion of these units in the manuscript texts, which, one would think, should lend them long-term stability, this is noteworthy. ${ }^{10}$

Notwithstanding the unusual text consistency of the two manuscript texts, I consider it unlikely that either served as immediate Vorlage for the production of

7 I here italicise Changes to indicate that unlike the manuscript text, the transmitted-and thus imperial-text most likely text makes reference to a defined body of Changes.

8 Riegel 1993: 293.

9 The Shànghăi manuscript has a text written on twenty-four slips about 54.3 centimetres long when complete, connected by three binding straps. Today only eight slips remain intact. See Shànghăi Museum 2001-, vol. 1:43-68, 169-213.

10 The two manuscript manifestations are organised as follows: The manuscript opening unit corresponds to unit 2 of the received "Zīyi”, followed by units 11, 10, 12, 17, 6, 5, 4, 9, 15, 14, 3, 13 , 7 (unit 7 is split into two in the manuscript texts), 8, 23, 18, 22, 21, 19, 20, 24. Units 1,16 , and the first part of 18 of the received text are not extant in the manuscript texts. For a discussion of the structural stability of manuscript “Zīyī”, see Kern 2005a. 
the other, as is indicative from certain structural differences between them. ${ }^{11} \mathrm{Be}$ cause variation is the norm in a manuscript culture, ${ }^{12}$ disparity between texts in general only offers limited information about their immediate relation. Some variances in the writing between the manuscripts fall into the category of graphic difference, ${ }^{13}$ others are phonetical. ${ }^{14}$ Differences of those two kinds are to be expected. They normally point to a situation where a given text may be relatively stable in its wording but not so stable in its written form, thus indicating a vital oral element in a text's use and transmission. This includes the possible scenarios where the writer in question-I am using the designation 'writer' for the person who executed the calligraphy on the manuscript as it does not carry the directional relationships between manuscript and text which copyist or scribe $\mathrm{do}^{15}-$ was reading the text aloud to himself or taking dictation when producing another copy of it, as this would result in a phonetically stable copy of the text, rather than a graphically stable one. This is a standard phenomenon in manuscript production more generally. ${ }^{16}$ Instances of this sort therefore offer only limited information about the stability of a text and do not concern us here.

We should look out for clues of a different sort. Particularly relevant is the situation where two (or more) different graphs represent broadly similar words (or not), but have a different phonetic value. Two main scenarios are normally considered for producing a copy of a text in manuscript cultures. First, a manuscript is reproduced from memory; secondly, it is reproduced from a physical Vorlage ${ }^{17}$ Yet the process is not so simple. The two models are not necessarily so different. To reproduce a manuscript from memory may also include taking the step via a physical Vorlage - and vice versa. The scenarios may therefore vary and may or may not involve third parties.

11 The term Vorlage is common in Biblical studies and does not carry the problematic connotations of the English 'source text'. Based on the Oxford English Dictionary, which defines Vorlage as 'original version of a manuscript or a book from which a copy is produced', I use it as thephysical-template of a given text.

12 In his seminal Eloge de la variante, Bernard Cerquiglini 1989: 111 remarks that medieval writing 'does not produce variants; it is variance' (L'écriture médiévale ne produit pas de variantes, elle est variance). It is important to note that this does not just characterise the European case of medieval writing, but equally applies to manuscript cultures more broadly, including those of early China. I come back to this.

13 See Boltz 1997: 258 for a discussion of graphic variation in manuscript texts.

14 See the discussion in Meyer 2011: 196, n. 32.

15 The term 'scripteur' would do the job too but I can see no advantage of it over 'writer'.

16 For European manuscript cultures see especially the informed discussion in Illich 1991.

17 To this date Kern 2002 has given the matter of manuscript reproduction in early China the fullest attention. 
One way to produce a new copy from a physical Vorlage is by dictation. This too may take two principal forms, each allowing for theoretically unlimited variations. First, the writers in question dictate the text they see to their own brush; second, someone is reading it out aloud to a writer, a situation reminiscent of the scriptorium in early medieval Europe. ${ }^{18}$ In either scenario, even though the writer is working from a material Vorlage, the oral value of the word may still by highly relevant or even take primacy over the structural features of the visible graph. This is of course not the only scenario. But it is common in manuscript cultures. China is no exception. ${ }^{19}$ To encounter the phenomenon in two structurally stable manscript texts where the type of variation is that two different graphs represent broadly similar words (or not) but have a substantially different phonetic value is therefore at odds with the habits of dictation, be it through a third party or by direct reference to a Vorlage (i.e., by dictating the word to one's own brush). This also includes text reproduction from memory. Should such phenomena occur in more than just one isolated instance, we can discount, as an informed hypothesis, the scenario that a writer was using one of two manuscripts, A or B, as a Vorlage for producing the other copy (A or B). In such cases we should therefore speak of each exemplar as a text in its own right.

To cite just one example taken from the manuscript texts "Zīyī", in a reference to Shū traditions, the Guōdiàn text has cāng 滄 (OC * $\left[\mathrm{ts}^{\mathrm{h}}\right]$ an $)$ where the

18 On manuscript production in early medieval Europe, see exemplary, Putnam 1962.

19 There are of course also plenty of examples where the writer went for the graph they saw, not its aural value. But such cases are not always easy to determine. For instance, when in a manuscript text certain graphs are sometimes written with a variable position of their phonophore or signific (i.e., left, right, top, bottom), it is not necessarily indicative of a visual copying from a physical Vorlage. Cases where a writer reproduced the graph they saw, not the sound they heard, have been made for various texts. The Qinghuá manuscript “^Mìng xùn” 命訓 (Instructions on Commands), for instance, reproduced in volume 5 of the Qinghuá Manuscripts, may be one such case, as suggested by Richter 2009. The manuscript “^Zhèng Wéngōng wèn Tàibó” (vol. 6) might be another reference point for visual copying. It comes in two manuscript recensions, * $A$ and ${ }^{\star} \mathrm{B}$, which systematically write place names differently while it seems that they were produced by the same writer. However, cases of visual copying are not the rule. Ignoring matters of phonetics, graphic variation between manuscripts is often explained by stating that the writer in question must have worked from different Vorlagen at hand, just because the position of the signific of a graph or so differs between two manuscripts. (Examples include Shaughnessy 2016b. A similar argument was made in Morgan 2010.) For a good discussion of the triangular relationship of graph, sound, and meaning, see Boltz 1994: 18-21.) Note in this context that in some of the states in the collection of verse of the Ân Dà Shi the writer clearly made a point about the deeper meaning of a word by playing with its written signification. It is impossible to say though whether this reflects a separate tradition of the Shì or simply answers to a rather idiosyncratic playfulness of the writer in question. This is discussed more fully in Meyer and Schwartz 2021a and b. 
Shànghăi manuscript has hán 寒 $\left(\mathrm{OC} *[\mathrm{~g}]{ }^{\mathrm{a}} \mathrm{a}[\mathrm{n}]\right) .^{20}$ While the two words appear sufficiently close phonetically on a superficial level, the place of articulation of the initial seems too different for assuming that it makes a good loan, and they also have a different coda. ${ }^{21}$ Although the two words basically share the same (broader) meaning, they differ (enough) phonetically. Examples of this kind abound. To me it suggests that the two manuscript texts are best considered as independent texts without a shared immediate transmission history. ${ }^{22} \mathrm{I}$ therefore treat them as though they each have had their own-and different-Vorlage. ${ }^{23}$ This does not of course mean that the two texts do not have a related history. However, unless we assume a creative reproduction of the text from its Vorlage, that is, the literarisation of the new text through productive polishing, we must suppose that neither of the manuscripts was produced by using the other as direct Vorlage. Given the type of variation in the manuscript texts, as well as the sort of text the manuscript versions of "Zìyi”" represent-they are neither representational in their literary style nor in their physical appearance-I consider the scenario of a creative reproduction unlikely.

In conclusion, the evidence suggests that Guōdiàn and Shànghăi “Zīyì” each represent an independent text. Despite some changes on the lexical level, common in a manuscript culture, the two manuscript texts are surprisingly stable in text composition, structure, and content. The two independent but highly stable manuscript texts to a rare degree cast light on the condition of text cohesion and writing in the environment of a steadying manuscript culture at around $300 \mathrm{BC}$.

20 Guōdiàn Slip 10/8; Shànghăi Slip 6/20. Baxter-Sagart 2014 reconstruct hán 寒 as OC ${ }^{\star}$ Cə. $[\mathrm{g}]^{\complement} \mathrm{a}[\mathrm{n}]$, but I think the prefix is not tenable. Schüssler 2007 reconstructs the pair OC *tshran(h) (for cāng 滄) and OC * gân (for hán 寒).

21 The criteria for phonetic similarity for loan characters and phonetic components in Old Chinese are as follows. (1) The main vowel should be the same; (2) the coda should be the same; (3) initials should have the same place of articulation (but not necessarily the same manner of articulation); (4) one may be A-type, one may be B-type; (5) one may have *-r- and the other not; (6) the 'tone' category may be different (i.e., final ${ }^{\star}$ ? and final ${ }^{*}$-s can be ignored). These rules are sometimes relaxed, as is evident, for example, by páng zhuăn 旁轉 phenomena, in which open and closed syllables are substituted for each other. (See Meyer 2011: 150, n71.)

22 This point is contested. Scott Cook (2012: 370) concludes the opposite. He takes the two instantiations of "Zìyì" fundamentally as the same text.

23 Other examples include graphs that differ phonetically, as well as in meaning. For instance, in a reference to the Songs, Guōdiàn has yi 義 ( $\left.{ }^{\star} n(r) a j-s\right)$ 'rightness'

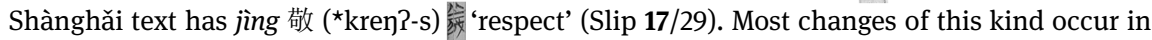
reference to Shū texts. In discussing “*Wǔwáng jiànzuò” A and B Krijgsman 2014b: 102n74 notes a parallel variation to the one under discussion, stating that although yi 義 and jing 敬 have some graphic resemblance, they are nonetheless easily distinguished. 
The Guōdiàn manuscript text "Zīyī” is written on forty-seven bamboo slips, each about 32.5 centimetres long. They are unusually well preserved. Not a single slip of this rather sizeable manuscript is fragmented. The slips are tapered towards both ends. As can be judged from the marks, two cords, 12.8-13 centimetres apart, previously kept the slips together. ${ }^{24}$ The Guōdiàn "Zīyî” is very likely complete, as is the Shànghăi. After each unit of thought there is a heavy black mark on the slips, structuring the text into twenty-three units. This number is also given at the end of the text, signalling that this is the full extent of the text. ${ }^{25}$ Given that the same number is produced in two independent manuscript texts, it is reasonable to assume that "Zìyī" in twenty-three units was considered one entity by at least some text communities. It is therefore likely that more such copies existed and that during the Warring States, "Zīyī" was considered a stable entity - otherwise it would not be necessary to provide that number at the end of the text. To assume that the number might serve to preserve the text in its given form-what German textual criticism calls Textsicherung-so as to guard the text against future rearticulations yields the same conclusion about the multiple circulation of a predominantly stable text. This is given further support by Shànghăi "Zīyì". The textual state of "Zìyī” thus explains the extraordinary coherence of the two manuscript versions of the text. ${ }^{26}$

In the manuscript texts the following units draw explicitly on Shū, the information in parentheses points to their counterpart in the received text: 3 ( $L$ iji 10$)$;

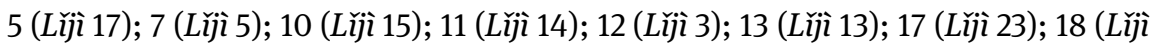
18). ${ }^{27}$ On altogether nine occasions the manuscript texts refer to text passages-or speakers (?)-of Shū traditions, while twelve units of the received "Zīyī" draw on the Shàngshū, some in more than just one instance. ${ }^{28}$ The most erratic of these is unit 16 of the received text, with four references to the Shàngshū. Notably, these are to the spurious “Tài jiă” 太甲 in two instances; “Yuè mìng” 說命 of the nebulous old-script-recension; as well as to a text generally taken as "Yǐn gào” 尹誥

\section{Guōdiàn Slips 1998: 129.}

25 Note that "Zīyī" is not the only text where numbers are preserved. Olivier Venture lists various cases, including manuscripts from the Eastern Hàn, that provide a word count at the end of the text in his Livres et documents dans la Chine ancienne, a systematic overview of text finds from early China.

26 Kern 2005a: 300-301 suggested that the macro-consistency of the excavated "Ziyyi” presents an effective tool for textual stability.

27 This exercise is greatly aided by Shaughnessy 2006.

28 The references to Shàngshū in the "Zīyì" of Ľ̉jì are in units 3 (manuscript unit 12); 5 (M17); 10 (M3); 13 (M13) in two instances; 14 (M11); 15 (M10); 16 (N/A) in four instances; 17 (M5); 18 (M18); 22 (M19); 23 (M17); 24 (M23). 
(but written as 尹吉 in the text). The transmitted unit 16 is not extant in the manuscript texts and is probably a much later intrusion. Equally interesting is the fact that while many of the references to Songs in both the manuscript and received recensions name them explicitly as Songs, there are no intertextual correspondences of that sort to Shū. In the manuscript texts Shū are never referenced in generic terms but always by specific designations - be they texts or the names of posited speakers.

\subsection{Shū in "Zīyī"}

I shall now present a brief overview over the ways "Zīyì" draws on Shū, exemplified through the Guōdiàn text representation.

Guōdiàn "Zīyî” unit 3:

The first unit that incorporates Shū in the manuscript texts is unit 3, cited fully above. ${ }^{29}$

Both the Guōdiàn and the Shànghǎi recensions reference Shū as Yĩn gào 尹 总 (誥). There is no such text in the received modern-script recension of the Shàngshu,$^{30}$ but a phrase similar to this one appears in pseudo-Kǒng "Xián yǒu yī dé”, as I outline below. ${ }^{31}$

Differences between Guōdiàn and Shànghǎi with regard to Shū correspondences are minor. They principally apply to two graphs: for graph 5/7 in Guōdiàn,

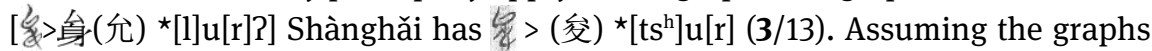
have been rendered correctly in the transcriptions, they are just graphic variations of the same character, a normal phenomenon in manuscript cultures and should not concern us here; for graph 5/9 in the Guōdiàn text, [㴚(湯) ${ }^{\star}{ }_{0}^{\mathrm{r}}{ }^{\mathrm{a}}$ )]

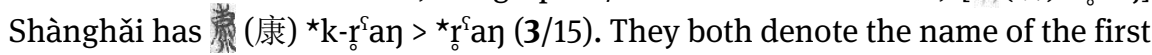
Shāng ruler. As in the example above they have the same phonetic value.

The old-script “Xián yǒu yī dé” has the following line: “惟尹躬暨湯，咸有一 德’ (in reaching out to Tāng, Yī ^Yĩn [and Tāng] both had one single mind), stably corresponding to “惟尹躬及湯, 咸有一德” from the Liji recension - except the fourth graph. But 暨 (*[m-k-]rəp-s) and 及 $\left({ }^{\star}[\mathrm{m}-\mathrm{k}-]\right.$ rəp) make a perfect loan and

29 See p. 64.

30 The Lỉjì recension of “Zīyī” has “Yĩn jî” 尹吉. Based on Zhèng Xuán, Shaughnessy 2006: 97, n. 46 speculates that the received recension confuses the title with one of a lost chapter of the Shàngshū, named Yĩn Jífŭ 尹吉甫 or Yĩn Jífù 尹吉父.

31 The old-script "Xián yǒu yī dé" was possibly produced by way of building the text around common phrases from known traditions. We therefore cannot determine the exact relationship of it with the Lǐji and other sources. 
can mean the same thing. The phrase appears similarly also in "^Yĩn gào" of the Qinghuá manuscripts: 隹(惟)尹既﨤(及)湯咸又(有)一真(德). ${ }^{32}$ The third graph,

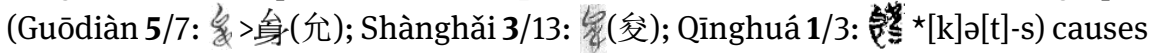
much confusion among the commentators and cannot be well explained either phonetically or graphically. ${ }^{33}$

Judging from the lexicon we may conclude that the two manuscript recensions of "Zīyī", Guōdiàn and Shànghăi, each show some graphic variations that do not, however, impair the texts' stability. Phonetically, however, they present a remarkably steady text. This aside, regarding their use of Shū traditions, the two manuscript recensions of “Zīyī” display a discrepancy from Qīnghuá “^Yĩn gào" pertaining to one graph in particular, which broadly speaking has the same meaning to the ones used in the other manifestations of textualised Shū but differs in ways that cannot be well explained phonetically or graphically. This suggests, again, that the three manuscript texts (the two manuscript texts "Zìyī" plus “^Y̌̃n gào”) were not produced from the same immediate Vorlage, or in fact, from one another. This should not come as a surprise. Nonetheless, it is crucial, methodologically, to make this clear. As a general observation, confirmed by the analysis of the other units in "Zìyī", there is a gap between received and manuscript texts: the received recensions of the referenced text (in this case, Shū as produced

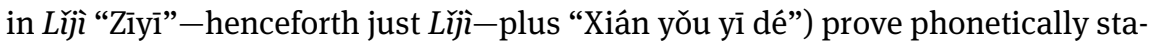
ble but present some notable discrepancies from the three manuscript texts.

Conceptually the analysis presents a different picture though. In the oldscript "Xián yǒu yī dé" the referenced text reproduces speech articulated by Yī Yǐn. This is not so clear in “Zìyī”. In “*Yǐn gào” the referenced passage is not part of Yī Yǐn's speech but constitutes a narrative by an off-text voice. This brings to light a marked difference between "Xián yǒu yī dé" on the one hand, and the manuscript text "^Yǐn gào" (and possibly "Zīyī” too) on the other. It shows that while the different texts clearly draw on a common fabula that frames the articulation of these texts in the first place, the story they produce from it is different in each case. This makes it plain that the communities in question each conceptualise quite differently the materials that underlie common text production.

32 Slip 1/1-9.

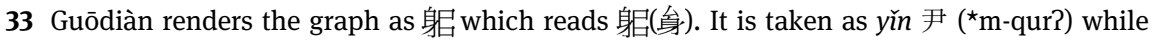
reading the preceding 尹 as $y \bar{\imath}$ 伊, which is unproblematic. Qiú Xīguī (in Guōdiàn Manuscripts: 132) interprets 牟 as yŭn 允 in the sense of an emphatic 'truly'. ji 既 (* $[k] \partial[t]-s)$ of the Qinnghuá recension is phonetically quite different different from $尹\left({ }^{\star} \mathrm{m}\right.$-qur?) or 允 $\left({ }^{\star}[1] \mathrm{u}[\mathrm{r}] \mathrm{P}\right)$ and thus poses a problem. 
Questions remain, in particular with regard to what this unit actually means, or what it sets out to do. Why have a master saying paired with lines from the Songs and Shū, without any supporting narrative that would help to conceptualise the three sources-master sayings, Shì, Shū-or make them somehow cohere?

The Shū phrase itself as produced in this unit says very little, except of course that two personae of high antiquity 'had one single mind'. This suggests that, as stored in this unit, the phrase is less about its actual content, but rather about the story behind the phrase to which it is pointing, but which today's student of early textuality can reconstruct only inadequately through the limited sources available, in particular the imperial Shǐji and Shàngshū, as well as other, epigraphical, materials. ${ }^{34}$ Whether the story as presented in them corresponds at all to the ways the communities around the manuscript texts "Zīyì" would conceptualise the role of these personae back then is yet another question.

When reading the old-script "Xían yǒu yì dé”, one of the extant sources available today, we see that it dwells on the notion that it is vital for a ruler to nourish their dé 徳, 'charismatic power', as a principle means to preserve their throne because it is 'difficult to rely on Heaven - its appointments are not constant' (天難 諶, 命靡常) $)^{35}$. That is why the rulers of high antiquity had to make sure their dé 徳 was constant. As long as a ruler's dé is unwavering, his ways are certain to be fortunate. As put by Yī Yǐn in "Xían yǒu yī dé”, the minister's task is therefore to promote the ruler's dé so it be unflagging. From this it follows that it ought to be the rulers' task to find, and appoint, ministers that ably do so.

That it is vital to nourish a ruler's 'charismatic power' so as to secure Heaven's commands (tiān mìng 天命) is not, however, a notion which features prominently in either Qīnghuá “^Y̌̃n gào”, or in the master’s saying as (re-)produced in the manuscript texts "Zīyī". Unlike "Xían yǒu yī dé”, the manuscript text “^Y̌n gào” dwells on the importance of keeping the support of the mín 民一for reasons of simplicity I here render the term as 'commonfolks' ${ }^{36}$-for they make

34 Some oracle bone inscriptions reference Yĩ Yĩn, and so it can be assumed that there really was a person of that name during Shāng times. As the name is preserved, it has historical significance (whether he really had the said importance as the principle minister helping his ruler, Tāng, to defeat Jié 桀 (leg. 1728-1675 BC) is another matter.) Next to Qīnghuá “ᄎYín zhì” and

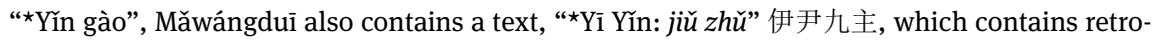
spective imaginings about Yī Yĩn. Láo Sīguāng 2003: 133 considers the text to be of Warring States origin. Reading "Zīyì” through the Mòzì, Andrew Meyer 2014 suggests a 'bidirectional' process between master sayings and foundational texts.

35 My translation here follows Legge, 1960: 213.

36 Obviously, min 民 is not equivalent to the 'people'. The term probably derived from denoting members of the aristocracy of a different state and took on the meaning of 'commonfolks' only 
the basis of a ruler's preservation of his throne. While the notion of preserving the throne thus features prominently in both "Xían yǒu yī dé” and "*Yĩn gào", it looks as though it is absent in "Zìyi”", where the clear confines of the different roles in government are stressed so that lords shall not 'doubt their ministers' and ministers 'shall not be confused' about their rulers. It is not difficult to imagine that the text communities around the "Zīyī" manuscript texts may have conceptualised the master saying in this way.

We further notice that, in the textualisations of Shū, the ideas about preserving the throne are developed quite differently. The phrase from the very begin-

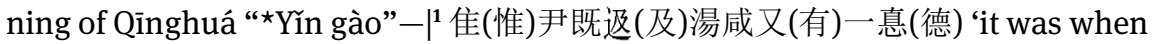
Yī [Y̌̃n] had joined Tāng that they had one shared mind'-serves as the opening peg of the text. While it brings to mind the exemplary pair of ruler and minister from bygone days, it remains conceptually detached from the subsequent dialogue between minister and ruler. This differs in "Xián yǒu yī dé" where it features more centrally.

Lastly, the phrase from the Songs as reproduced in "Zīyī" simply mentions the standards of the noble man. When looking into the ode "Shījiū" 隝鳩 (turtledove) as it is transmitted and therefore, at least theoretically, a (remotely) possible source behind the phrase in "Zìyì", we see that it suggests that it is through the deportment of virtuous men that the 'four quarters of the state' can be 'rectifed' (淑人君子正是國人) for 'myriad years' (萬年). ${ }^{37}$

In conclusion, this brief conceptual overview casts light on four phenomena. First, the unit of the "Zīyì" contains a thematic grouping of three separate sources, consisting of master saying; Shì; and Shū. This confirms the picture of the stabilising tripartite structure of ž̀-Kǒngzì (?)-and the foundational texts, Shī and Shū, of the analysis in Chapter One. Second, because the linguistic content of these sources as produced in this unit is rather limited, it becomes clear that the

in the course of the Warring States. I discuss this in further depth in my Conclusion. Today's misconception of mín as 'people' in the Shàngshū largely derives from Legge's conceptualisation of that term. Although Legge himself was well aware of the commentaries that understand it rather differently, his translation primarily reflects ideological, that is, Protestant purposes and has to be understood in the context of the Scottish Enlightenment ('everybody has access to the message of God' - personal communication with Joachim Gentz, September 2015). Later, however, it came to influence Western scholars' understanding of that term as 'people' more generally. See also Gassmann 2000 for a discussion of min, which suffers, however, from overcategorisation. A more nuanced reading is given in Crone 2014 and 2016. Grundmann 2017 takes it to denote a political idea, Zhōu kingship, rather than actual social groupings.

37 Máo "Guófēng": 152. It is vital to keep in mind, however, that the Máo recension is of imperial making. The song is not part of the Ân Dà Shì. 
conceptualisation of the phrases, if it occurred, must have taken place in a setting outside the written text, reflecting either a teaching situation or marking "Zīyī" as a text speaking only to groups of insiders. Third, it seems unlikely that the master saying provides any sort of conceptualisation of the Shī and Shū as produced in the text, for it is itself too enigmatic to cast light on a third source. Therefore, rather than reading Shì and Shū as reproduced in "Zīyì" through the master sayings, it seems as though the three feature co-ordinately, that is, as separate cultural resources collected in one unit, figuring on the same conceptual plane. Lastly, there are broadly speaking three separate interpretations in the use of the fabula related to Yī Yǐn as reproduced in this unit. These are, first, the transmitted recensions of Shàngshū and Lǐji ; they display some marked differences to the three manuscript versions of the referenced text. But the three manuscript texts must also be grouped, and a distinction made, between the two "Zīyī" texts on the one hand, and the Qinghuá manuscript text, on the other. ${ }^{38}$

It seems as though the unit under review acted like an archive, storing items of cultural significance. It contains a repertoire of key modules of learning ascribed to Master, Shī, and Shū, put together by themes. The units that follow largely confirm this as the broader picture: first regarding the ways the three sources feature co-ordinately in the "Zìyi”" manuscript texts, thus serving as some form of storehouse for cultural capital that is conceptualised outside the written text; second, the textualisations of Shū as produced in "Zīìī" feature as unfixed entities referencing different fabulae, which, in each case are given contrasting representations in textual form by different conceptual communities.

Guōdiàn “Zīyī” unit 5:

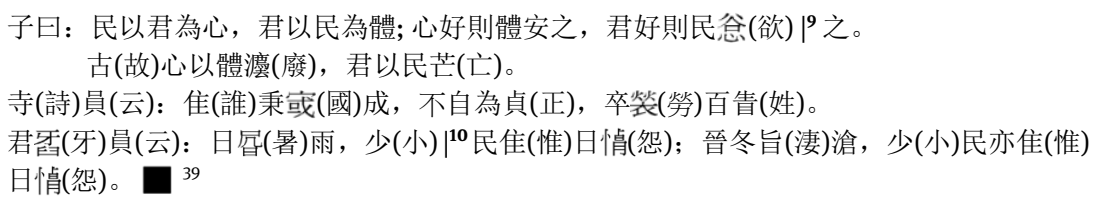

The Master said: 'The commonfolks take the lord as their heart (-mind), the lord takes the commonfolks as his body; when the heart (-mind) is good then the body will find comfort in it, and when the lord is good the commonfolks will desire ${ }^{9}$ him'.

This is why 'the heart (-mind) is laid waste by the body and the lord may disappear on account of the commonfolks'.

38 Whether the comparable stability of Shū references between the two "Zīyì" recensions says more about the stability of "Zìyì" than the Shū is a question that occupies me further below.

39 Guōdiàn "Zīyī" unit 5 (Lỉì 17): Slips 8/7-10/14. For the reconstruction of the text, see Shaughnessy 2006: 100-101; S. Cook 2012: 384-386. 
Songs say: 'Who is it to hold to the accomplishments of the state? Not serving as the standard himself, in the end he belabours the many surnames.

Lord Ya (君牙) said: 'when summer rain comes daily - the petty $1{ }^{10}$ commonfolks resent it more by the day; when the brisk cold of winter approaches - it is equally that the petty commonfolks resent it more by the day'.

The reference structure of the unit presents the phrase as though it was given by the speaker Lord Ya (jūn yá ), not a text. ${ }^{40} \mathrm{~A}$ text of the name “Jūn Yá” 君牙 (Lord Ya) is, however, part of the pseudo-Kǒng recension of the Shàngshū.

Shànghăi "Zìyi”" references the saying by Lord Ya in the same way. But it displays some discrepancies from the Guōdiàn text in the contents of that phrase.

“Jūn Yá” 君牙 (Lord Ya) contains the following line: 夏暑雨，小民惟曰怨咨; 冬祁寒, 小民亦惟曰怨咨 (in the heat and rains of summer-the petty commonfolks can be described as murmuring and sighing; and so too can they be described in the great cold of winter); the Liji has instead 夏日暑雨，小民惟曰怨。 資冬祁寒，小民亦惟曰怨 (with the hot rain of summer rains-the petty commonfolks can be described as resentful; and so too, with the bitter cold of winter-the petty commonfolks can be described as resentful). The difference between 咨 $\left({ }^{\star}[\mathrm{ts}] \mathrm{ij}\right)$ and 資 $\left({ }^{\star}[\mathrm{ts}] \mathrm{ij}\right)$ is purely graphical and therefore negligible; other changes include the additional use of 'day' (日) in the Lǐji recension plus the reference to the text as “Jūn Yá” 君雅 (rather than 君牙) in the old-script recension. They have no bearing on the stability of the text.

With reference to Shū, the differences between Guōdiàn and Shànghăi are altogether minor; ${ }^{41}$ the text of the Lĭji recension broadly corresponds to the

40 I elaborate this in more detail in my conclusion.

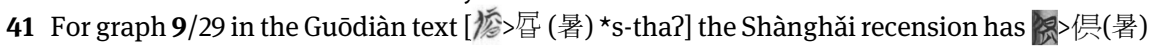
${ }^{\star} \mathrm{s}$-tha? (6/10), but its components seem to correspond. This difference is graphical, not structural, because the components of the two seem to correspond fully. It displays a kind of variation typical in manuscript cultures and should therefore not concern us here; next is Guōdiàn 曷 > 㥜 (怨) *[?]o[r]-s 'resentment' (10/4), rendered as 复 (命) *m-rin-s 'command' (6/16) in the Shànghăi recension. Note, however, that Lǐ Líng 2002b: 410 suggests that the graph in question (侅) is really a form of 怨 'to resent'. 'Winter' 冬 * $t^{\mathrm{S}} \mathrm{u}$ ) has an additional signific in the Shànghăi recension 冬(冬) which has no bearing on the stability of the text (6/19-20). The pair 旨(淒)滄 in Guōdiàn $(10 / 7-8)$ is rendered as 耆寒 in the Shànghăi text (6/18). While the first graph just has an additional signific in the Shànghăi recension (老), which has no bearing on the text's stability, the second graph, while representing broadly the same word, differs graphically as well as phonetically 滄 *[ts $\left.{ }^{\varsigma} \mathrm{h}\right] \mathrm{an}$ / 寒 *Cə.[g] $]^{\varsigma} \mathrm{a}[\mathrm{n}]$. (Guōdiàn Slip 10/8; Shànghăi Slip 6/20.) As mentioned above, this difference suggests that the two manuscripts were not copied one from another, or in fact had a common (!) third source. 
Shàngshū with just some insignificant changes. However, as seen from the previous unit (Guōdiàn "Zīyì" 3), there are some notable differences in the use of Shū between the manuscript texts on the one hand, and the received texts on the other. We see a text in various recensions that is constant with regard to the fabula that informs text production, but with some instabilities in its rendering as actual text.

As in the previous unit (3), the master saying is itself not obviously elaborating the Shū phrase. It is itself too enigmatic. Its inscrutable nature therefore confirms that in "Zīyī" the sources feature co-ordinately, not hierarchically. As none of the three voices conceptualise any of the other (as in Shĩ and Shū through ž̀ 子), it appears that the master saying, $z \check{\imath}$ 子, is itself part of the repertoire of cultural learning, reproduced-and thus stored-in "Zìyi”. ${ }^{42}$

Despite these commonalities, the structure of this unit is intriguingly different from unit 3. Unlike in the previous instance, the master saying is broken up by a reflecting comment, marked by 'gü' ('this is why'). It is not clear whether it actually belongs to the master saying. Two features suggest it does not ${ }^{43}-$ first, the regularity with which it occurs in "Zìyì"; second the link it provides thematically between the cultural resources of $z \grave{l}$, Shī, Shū. Because of its structuring feature with regard to the cultural resources within the space of "Zìyi", methodologically I therefore take it as its authorial voice.

Guōdiàn "Zīyī” unit 7:

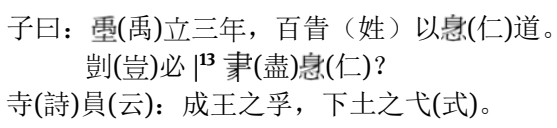

For the remainder of the line, 少(小)民亦隹(惟) 日㥜(怨) in the Guōdiàn recension of “Zīyī”, Shànghăi reproduces the previous difference and renders the Guōdiàn graph 㥜(怨) as 令(令). (The stroke on the lower right is the unit marker and not part of the graph in question.)

42 This interpretation still holds if assuming, quite possibly, that only the first half or so of the phrase is spoken by zǐ, with the remainder of that phrase introduced by gù 'this is why [it is said]' belonging to the authorial voice of the text. Because this would be an obvious break from the pattern to the contemporaneous audiences as all the other phrases belong to a community's cultural capital, it would be a 'principle insertion' and thus formulate the unit's central concern. It would add to "Zīyì" an argumentative layer commonly unnoticed in the scholarship. 43 In his seminal study of the manuscript texts from Guōdiàn, Scott Cook (2012: 372f) persuasively points to this possibility by reference to the Qing scholar Chén Lí 陳澧 (1810-1882). My conclusion is also informed by a conversation with William French (South Bend, IN, October 2018). 


\section{郘(呂)基(刑)員(云): 一人又(有)慶，澫(萬)民贎(賴) $\left.\right|^{14}$ 之 $\mathbf{D}^{44}$}

The Master said: 'When [the Great] Yu had been in position for three years, the many surnames were all led by humaneness'.

'How could it be that they were ${ }^{13}$ all humane?'

Songs say: 'The faithfulness of King Cheng is the model of the lands below'.

In Lü's penalties (呂刑) it is said: 'when the One man excels in virtue, the myriad folks [all] rely on $\left.\right|^{14}$ him'.

This passage above refers to “Lü xíng” 呂刑 ( ${ }^{\star}$ ra? * $\left.[\mathrm{G}]^{\varsigma} \mathrm{en}\right)$. The Lǐji recension consistently renders it “Fǔ xíng” 甫刑 $\left({ }^{\star} \mathrm{p}(\mathrm{r}) \mathrm{a}{ }^{\star}{ }^{\star}[\mathrm{G}]^{\mathrm{S}} \mathrm{en}\right)$, an unproblematic phonetical change that should not concern us. A text “Lǔ xíng” 呂刑 is part of the modernscript recension of the Shàngshū.

With the exception of 贎 (賴) ${ }^{\star} \mathrm{r}^{\mathrm{S}} \mathrm{a}[\mathrm{t}]-\mathrm{s}$ in Guōdiàn (13/22), rendered 訉 in the Shànghăi manuscript, the two manuscript recensions can be described as consistent, ${ }^{45}$ with just a few graphical differences between the two that do not affect the stability of the text and can therefore be disregarded..$^{46}$ The received "Lü xíng" reads 一人有慶, 兆民賴之 (when the One Man excels in virtue; the 'multitudinous commonfolks' rely on him). The Lǐji recension is identical to the Shàngshū. Instead of wàn mín 澫(萬)民 as in the manuscript recensions, it has zhào mín 兆 民 the 'multitudinous commonfolks'. ${ }^{47}$

44 Guōdiàn "Zīyì” unit 7 (Lǐji 5): Slips 12/11-14/1. For the reconstruction of the text, see Shaughnessy 2006: 103; S. Cook 2012: 388-389.

45 Note, however, that the identification of 贎 as lài is not entirely unproblematic because lài 賴 reads ${ }^{\star} \mathrm{r}^{\mathrm{S}} \mathrm{a}[\mathrm{t}]$-s while the phonophore in 贎 is 萬 ${ }^{\star} \mathrm{C} . \mathrm{ma}[\mathrm{n}]-\mathrm{s}$, which is a problem on both phonetical and graphical grounds.

46 It should be pointed out though that 訉 is an unknown graph that has not been analysed properly. See however Xú Zàiguó and Huáng Dékuān 2003; Bái Yúlán 2002 who take dà 大 ( ${ }^{\star} l^{\complement}$ ats) as the phonetic element and read it as 賴 ( $\left.{ }^{\star} \mathrm{r}^{\mathrm{S}} \mathrm{at}-\mathrm{s}\right)$ as they do in the Guōdiàn recension; Zāng Kèhé 2003 tries to argue that $d \grave{a}$ 大 here is actually ér 而 and sees the graph as a variant of tiáo 誽, here rendered as lài 賴.

47 The phrase 兆民 appears regularly in the old-script recension of the Shàngshū: "Wǔ zĩ zhī gē" 五子之歌; “Zhònghuǐ zhī gào” 仲迪之誥; “Tāng gào” 湯誥; “Yī xùn” 伊訓; “Yuè mìng” shàng 說 命上; “Wǔ chéng” 武成; “Zhōu guān” 周官 (four times). The one use in “Lü xíng” is its sole occurrence in the modern-script recension. The term wàn mín 萬民 as used in the manuscript recensions presents the opposite picture. Except for one occasion, it is used exclusively in texts of the modern-script recension: Twice in “Pán gēng” 盤庚; twice in "Wú yì” 無逸; once in "Jūn chén” 君陳. Whether this distribution pattern points to a late modification where the term zhào min 兆民 is used is difficult to ascertain (Chéng Yuánmǐn 1999 arrives at this conclusion). The Zuǒzhuàn ("Mǐngōng yuán” 閔公元年: 1.6) conceptualises it as follows: 'for the son of Heaven [one] says zhào mín (multitudinous commonfolks); for the many Hóu [one] says wàn mín (myriad commonfolks)' 天子曰兆民, 諸侯曰萬民. Yáng Píngnán 2001: 259 notes that in bronze texts the 'Son of Heaven' is sometimes addressed as zhào mín. 
While in the previous units the immediate relation of the three resourcesmaster saying, Shì, Shū-is of an intuitive nature only, here they cohere more consistently in the topos of the exemplary person and their impact on the people. The master saying brings in the memory of the Great Yu (Dà Yú 大禹) and the subsequent transformation of the people; the phrase from the Shi dwells on the model king, King Cheng (Zhōu Chéngwáng 周成王, r. 1042/1035-1006 BC) for 'the lands below'; Shū remains generic in this respect but essentially reproduces a related thought. The authorial voice brings this to the fore, though in this unit it produces a rhetorical question rather than a marked 'gù' statement. ${ }^{48}$ Thematically its organising function remains nonetheless.

Guōdiàn “Zìyī” unit 10:

子曰: 大人不新(親)其所臤(賢), 而 $\left.\right|^{18}$ 信其所戔(賤), 㝘(教)此以遊(失), 民此以綽(煩)。 寺(詩)員(云): 皮(彼)求我則, 女(如)不我得, 執我 $\left.\right|^{19}$ 求 $=($ 仇仇 $)$; 亦不我力。

君迧(陳)員(云): 未見聖, 如其弗克見; 我既見, 我弗迪聖。

The Master said: 'When the superior man does not hold dear those he considers worthy but ${ }^{18}$ places trust in those he considers vulgar, then instructions will be lost and the commonfolks will be troubled'.

Songs say: 'Those sought for me as [their] model. Should they not get me, they will hold me ${ }^{19}$ in animosity; ${ }^{50}$ surely they seek no strength in me'.

Lord Chen (君陳) said: 'while not having seen a sagacious person it was as though it was impossible for him to be seen; once I had seen [him] I failed to make use of [him], the sagacious one'.

As before, "Zīyī" seems to take Lord Chen as a speaker rather than a text. But a text named “Jūn chén” 君陳 (Lord Chen) exists in the pseudo-Kǒng recension of the Shàngshū.

Shànghăi introduces the phrase as 君縄(陳). This is a mere graphic difference to the Guōdiàn text and can therefore be ignored..$^{51}$ The Lijji recension has a linguistically close rendition of this as 未見聖, 若己弗克見, 既見聖, 亦不克由聖

48 S. Cook (2012: 388f) does not break it off but takes the line as belonging to the $z$ ǐ saying.

49 Guōdiàn "Zìyī" unit 10 (Lüji 15): Slips 17/16-19/23. For the reconstruction of the text, see Shaughnessy 2006: 105-106; S. Cook 2012: 394-395.

50 This reading is inspired by S. Cook (2012: 395).

51 Other instances of that sort include graphical differences in the word for shèng 聖 ( ${ }^{\star}$ len-s) written without the signific as 取 in the Shànghăi manuscript text, a common writing for the word 聖 in manuscripts from the Chǔ area; after 未見聖, 如其 the Shànghăi text displays a mark on the slips (=) which is normally used for reduplicating a word (Shànghăi Slip 11/3); instead of dí 迪 (谒) (Guōdiàn Slip 19/22) in the Guōdiàn manuscript text 我弗迪聖, the Shànghăi text has 曾(Shànghăi Slip 11/12). This was rendered as gui 貴 ( ${ }^{\star}$ kuj-s) 'precious; to honour’ by the editors 
(While not having seen a sagacious person it was as though he couldn't be seen; once he was seen, surely we were unable to follow along with him); ${ }^{52}$ the oldscript Shàngshū has 凡人未見聖, 若不克見; 既見聖, 亦不克由聖 (generally speaking, while men have not yet seen a sagacious person, it is as though they should never catch sight of him; once they have seen him, surely they are unable to follow along with him). The textual differences between the different recensions show a slight alteration in the understanding of the matter, unsurprisingly perhaps, but indicating the interpretative interruption of the phrase. It therefore appears that while the two manuscript texts (Guōdiàn and Shànghăi) display notable textual stability, that same text cohesion does not extend to the old-script Shàngshū, despite some significant textual overlap suggesting a close textual affinity. Albeit not conclusive, the line nonetheless supports Michael Nylan's hypothesis that the pseudo-Kǒng texts present 'deutero-canonical' knowledge in that they contain 'genuinely old material' that was then 'spliced with newer bridging passages of later date to form coherent narratives' ${ }^{53}$

When looking for a connecting thread between the three resources-master saying, Shì, and Shū-the theme of the recognition of the worthy one springs to mind. The song, produced from the posed perspective of the non-recognised, if indeed it is permissible to be reading the line through the received Shijing, ${ }^{54}$ is lamenting the destruction of the capital of the Western Zhōu as no support is sought from the aides (note that this is, however, not clear when seeing the phrase as produced in this unit in isolation); the downfall of Yīn 殷, caused by the disobedience of the people as a result of the rulers' lack of $d e$ 德, 'charismatic power', is central in the received "Jūn Chén" (again, that piece of information is not available in the phrase as reproduced in "Zīyì"); the Shū phrase identifies the lack of trust in capable aides as the source of misery.

The master saying provides no guidance as to how we should read and contextualise the Shī or Shū phrases. Instead, it is by introducing the matter of the sovereign as against the worthy one that the unit creates a platform of thematically related phrases from high antiquity. Unit 10 thus confirms the picture of "Zīyì" as gathering three parallel resources in the place of the text, speaking to

of Shànghăi Museum. (Shaughnessy 2006: 196, n. 63 suggests that the correct transcription of the graph should also have the phonophore 由 $\left.{ }^{\star}[\mathrm{u}]\right)$.

52 Note that phonetically rú qí 如其 (OC *na-gə) was close to ruò jǐ 若己 (OC *nak-kə?).

53 Nylan 2001: 131. For the Greek application of this phenomenon, see Collins 2002: 82-97.

54 Shì: "Zhèng yuè" 正月 (Máo "Minor elegantia" 小雅: 192). I do not suggest this was necessarily the reading of the contemporaneous text communities around the manuscript texts "Zìyī". 
an audience of insiders as no contextualisation of the resources appears in the text. The authorial voice is, however, conspicuously absent from this unit.

Guōdiàn "Zīyī” unit 11:

子 $\left.\right|^{20}$ 曰: 大臣之不新(親)也, 則忠敬不足,而㽬(富)貴已吪(過)也。邦舜(家)之不寜(寧) $\left.\right|^{2 \mathbf{2 1}}$ 也, 則 大臣不台(治),而埶(褻)臣忱(託)也。此以大臣不可不敬,民怄之蒛(蕝)也。

古(故) $\left.\right|^{22}$ 君不與少(小)怄(謀)大,則大臣不㥜(怨)。

並(晉)公之悬(顧)命員(云):冊以少(小) (謀)敗大 $\left.\right|^{23}$ 㥩(圖), 冊以卑(嬖)御息(息)55 妝(莊)句(后), 冊以卑(嬖)士息(息)大夫、卿事(士)。

The Master ${ }^{20}$ said: When great ministers are not held dear [by their lords], fidelity and respect will not suffice while wealth and honours will be in excess. When the state and the household are not peaceful $\left.\right|^{21}$, the great ministers will not be orderly while the dirty ones confide. It is for this reason that great ministers cannot but be respected - for they are the indicators of rank for the people'.

This is why 'when the ${ }^{22}$ gentleman does not scheme great [things] with petty ones, then what is great shall not be resented by the ministers.

The testimentary charge of Jin Gong (晉公之顧命) says: 'You shall not defeat the great $\left.\right|^{23}$ plans on account of petty schemes; you shall not retire the stately consort on account of favoured concubines; you shall not retire great officers and elevated officials on account of favoured men'.

The passage contains no reference to Songs. The oration used has no equivalent in the Shàngshü. However, there are some correspondences with a chapter of the Yì Zhōushū (Remnants of the Documents of Zhōu).

In Guōdiàn the text calls the orator of the speech as 整>曾(晉)公 Jìn Gōng

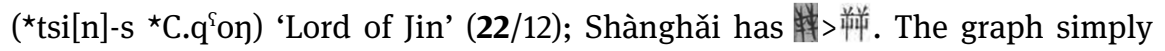
lacks the signific but represents essentially the same word 晉 *tsi[n]-s (12/22), a change that can be ignored. ${ }^{57}$ Besides the Yì Zhōushü there is also some significant overlap with Qīnghuá “`Zhàigōng zhī gùmìng” 祭公之顧命 (Testimentary charge of Lord Zhai), a Warring States text that is a potpourri of phrases from the Shū traditions; compositionally the features of "^Zhàigōng zhī gùmìng” are rem-

55 I do not share S. Cook’s 2012: 398 decision, guided by the received text, to read 22/6 息(息) as ji 疾 (^dzit) 'to distress'. (The same applies to 22/13.)

56 Guōdiàn "Zīyì” unit 11 (Ľ̌jì 14): Slips 19/24-23/16. For the reconstruction of the text, see Shaughnessy 2006: 107-108; S. Cook 2012: 395-397.

57 Note that Lǐ Xuéqín 1998: 44-45 claims that the Guōdiàn graph 前(晉) should in fact be read as 祭 (*[ts]et-s) in reference to Zhàigōng 祭公. It would thus correspond (too well?) to a text of that title in the Yì Zhōushū that corresponds to the referenced line. 
iniscent of the Yì Zhōushū where old cultural capital is brought together at some-

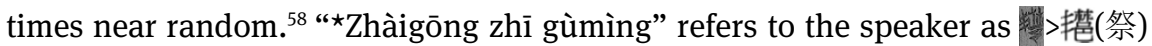
公 Zhài Gōng (Lord Zhai). ${ }^{59}$ The Ľj̉i recension has 葉公 Yè ( $\left.{ }^{\star}[\mathrm{a}] \mathrm{p}\right)$ Gōng (Lord Ye).

For the most part the Guōdiàn and Shànghăi manuscripts present a stable text. Differences between the two are mostly insignificant. ${ }^{60}$ The Yi Zhoushu markedly deviates from the manuscript texts, while the structure of its narrative is largely compatible:

公曰: 鳴呼! 天子, 我丕則寅哉寅哉! 汝無以戻反罪疾, 喪時二王大功, 汝無以嬖御固 莊后, 汝無以小謀敗大作, 汝無以嬖御士疾莊士大夫卿士, 汝無以家相亂王室, ...

The lord said: 'Alas!' Son of Heaven, we shall greatly make a standard with respect, with respect! You shall not change your own ways because of a transgression, thus losing the great achivements of the [former] two kings, (Wén and Wǔ). You shall not find fault with the established stately consort because of any favoured concubines; you shall not thwart the great deeds because of petty schemes; you shall not find fault with your great officers

58 For photographic reproductions of the slips and the philological annotations, see Qinghuá Manuscripts 2010-, vol. 1: 22-24; 99-113; 173-179.

59 Qīnghuá “^Zhàigōng zhī gùmìng” Slip 1/5-6.

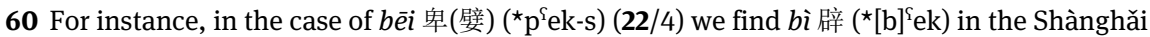
text (12/37), a mere graphical change, typical of texts in manuscript cultures and so it should not concern us here.

The corresponding item for graph 22/6 in the Guōdiàn recension 息(息) ‘to extinguish' as used in the Shànghăi manuscript text might perhaps present a problem. The corresponding item for graph 22/6 in the Guōdiàn recension is 覀 * $\mathrm{q}^{\mathrm{h}} \mathrm{\partial}$ (12/39). That graph is much discussed in the literature. The graph from the Guōdiàn manuscript一息(息) *sək ‘to extinguish’-is sometimes interpreted as $j i$ 疾 ( $\left.{ }^{\star}[\mathrm{dz}] \mathrm{it}\right)$ 'to distress', which is certainly guided by the Lǐji recension of “Zīyì”. (The discussion is well summarised in S. Cook 2012: 398, n. 144. I discuss the Guōdiàn graph in reference to the Liji text below.) That choice was justified by taking 自 ( ${ }^{\star} \mathrm{s}$. [b]i[t]-s) as the phonetic element, read 疾 (*[dz]it). (Xú Zàiguó and Huáng Dékuān 1998.) While the reconstruction as presented by the editors is to some extent guided by the wish for textual cohesion, the graph has nonetheless little bearing on the overall cohesion of the two manuscript texts. It is, however, not the only instance where the wish for textual cohesion guides the editors' choice of reconstruction. Other examples include the following: for the final two graphs in the text, the Guōdiàn recension has qing 卿 ( ${ }^{\star} C . q^{\mathrm{h}}$ ran) shi 事(士) while the Shànghăi text has xiàng 向 (*nan-s) shì 事(士). Because 向 (*nan-s) is close to 鄉 ( ${ }^{\star} q^{h}$ an-s) phonetically, and 鄉 is close to 卿 graphically, some scholars like to think the Shànghăi 向 is the result of 'miscopying' qīng 卿 as xiāng 鄉 (See Liú Lèxián 2002) - another strenuous explanation. 
and elevated officials because of favoured men in office; you shall not bring chaos to the kingly chambers because of private confidants (or your own surname), ... ${ }^{61}$

While structurally it is closer to the manuscript texts, the $L$ iji recension shows some notable overlap with the Yì Zhōushū in terms of its lexicon:

葉公之顧命曰:冊以小謀敗大作, 冊以嬖御人疾莊后, 冊以嬖御士疾莊士夫卿士。

The testimentary charge of Yè Gōng says: do not defeat the great deeds because of petty schemes; do not distress the stately consort because of favoured concubines; do not distress established officers and the elevated officials because of favoured officers. ${ }^{62}$

Much in line with the Yì Zhōushū, then, “^Zhàigōng zhī gùmìng” reads, within a longer catalogue of prescriptions:

公曰: 於(鳴)虎(呼), 天子...女(汝)母(冊)以俾(嬖)剷(御)息尔(爾)践(莊)句(后), 女(汝)母(冊) 以少(小)䏝怄(謀) 敗(敗)大虑(作), 女(汝)母(冊)以俾(嬖)士息夫三(大夫)卿攀(理), 女(汝) ${ }^{17}$ 母(冊)各愛(家)相而室...

The lord said: 'Alas!' Son of Heaven ... You shall not extinguish the stately consort because of favoured concubines; you shall not defeat the great deeds because of petty schemes; you shall not extinguish great officers and elevated officials because of favoured men; you shall not bring chaos to the kingly chambers because of the household, ... ${ }^{63}$

The recensions of the Yì Zhōushū on the one hand, and the Qinghuá manuscript text on the other, are fairly stable with regard to what they say, as well as the first few expressions used. Qīnghuá simply does not contain the first person pronoun of the line 我丕則寅哉! ('we shall greatly make a standard with respect') and it also does not repeat the marked stress yín zāi 寅哉. The negative imperative in Qinghuá is identical to that of the other manuscript texts, while the Yì Zhōushū is closer to the Lijì. There are other differences, of which some may well reflect an altered understanding of the text. ${ }^{64}$ For the most part, however, the differences

61 Yì Zhōushū huìjiào jízhù: 936-939.

62 Lìjì zhùshū: 931.

63 For comparison of “`Zhàigōng zhī gùmìng” with the passage in the Yî Zhōushū see Shaughnessy 2012. Shaughnessy concludes that the lexical variation between the Qinghuá recension and that of the Yì Zhōushū results from copying errors when consulting the same Vorlage.

64 Differences apply for instance to the line 汝無以戻反罪疾, 喊時二王大功 'You shall not change your own ways because of a transgression, thus losing the great achivements of the [for-

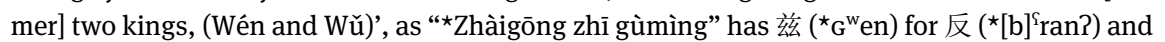
亡 ( $\left.{ }^{\star} \mathrm{man}\right)$ for 麁 $\left({ }^{\star} \mathrm{s}-\mathrm{m}^{\mathrm{S}} \mathrm{a \eta}\right.$-s). While the latter difference is unproblematic phonetically, the former can neither result from oral transmission nor from a graphical similarity, which tells against 
between the texts are of a kind one can expect in a manuscript culture. But as in the examples above, some differences cannot be explained on purely phonetic or graphic grounds. ${ }^{65}$

These observations lead to two conclusions. First, some of the changes reflect an interrupted line of understanding between the text of the Yì Zhōushū on the one hand, and the Qīnghuá “^Zhàigōng zhī gùmìng” on the other. It appears as though the differences between the two recensions do not result primarily from an oral text condition, nor do they reflect scribal 'errors' in copying from a given Vorlage (or one from another). Instead, the picture we get is of a different sort, suggesting independent instances of text production. Albeit they reference the same fabula, the story they produce from it differs. Second, because both the Guōdiàn and Shànghăi recensions of "Zīyī” are tightly organised around the Shì and Shū, the inclusion of the passage known from the Yì Zhōushū shows that at least certain text communities around 300 BC considered the traditions that we now see reflected in the Shàngshū and the Yì Zhôushū as related, so they would not distinguish between them. This is insofar noteworthy as a comprehensive study by Yegor Grebnev has shown there are marked differences between these two miscellanies (as well as earlier epigraphical materials) in composition, framing strategies, and recurrent text formulae. ${ }^{66}$ "Zīyi”" thus complicates the picture

the assumption that the two recensions result from the same Vorlage, or one from another; instead of 二王大功 'the great achievements of the two kings', “`Zhàigōng zhī gùmìng” furthermore has 遠大邦 ‘the great state afar’.

In 汝無以嬖御固莊后 'you shall not extinguish the stately consort on account of favoured concubines' Qīnghuá additionally has xī èr 息爾, and in 汝無以嬖御士疾莊士大夫卿士 'you shall not extinguish great officers and elevated officials on account of favoured men' it lacks yù 御 plus zhuāng shi 莊士 and, just like the other manuscript texts, it uses $x \bar{\imath}$ 息 in the place of $j \bar{\imath}$ 疾. Where the received text has 汝無以家相亂王室 “you shall not bring chaos to the kingly chambers because of the household' “`Zhài gōng zhī gù mìng” adds gè 各, and instead of luàn wáng shi 亂 ( $\left.{ }^{\star} \mathrm{r}^{\mathrm{\Sigma}} \mathrm{On}-\mathrm{s}\right)$ 王室 it has xiāng ěr shi 相( $\left.{ }^{\star} \mathrm{sa \eta}\right)$ 而室 - again displaying some differences in understanding. The connection with the next sentence is constructed by the co-ordinate connective particle ér 而 in the Yì Zhōushū while “*Zhàigōng zhī gùmìng” constructs a subordinate sentence through rán 然. While this creates a different stress, it may be easily explained on graphic grounds. For the phrase 尚皆以時中又萬國 in the Yì Zhōushū “^Zhàigōng zhī gùmìng” has the modal particle

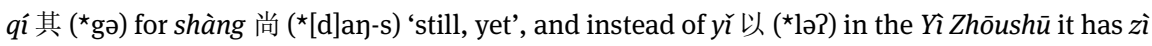
自 $\left({ }^{\star} \mathrm{s}\right.$.[b]i[t]-s).

65 It therefore seems they result from independent texts that did not share the same Vorlage.

66 Grebnev 2017a. Besides the differences in the prevailing contextualisation patterns in the Shàngshū and the Yì Zhōushū in structure and function, Grebnev further shows that the differ- 
of the Shàngshū and the Yì Zhōushū by casting into sharper relief their use by overlapping text communities before they were channelled into the current miscellanies. It becomes clear that Shàngshū and Yì Zhōushū simply represent interpretative lines of wider Shū traditions as organised by later, most likely imperial, communities. At least for some text communities, the distinction did not exist during the Warring States.

The master saying is uniquely long - even if we take the statement following gù 'this is why' as the unit's authorial voice. More obviously than in the previous examples this voice structures the unit thematically. But just as in the previous instances, it does little to contextualise, let alone conceptualise, the Shū or any other resource, Shī or žr. It simply remarks a shared concern about the integrity of ministers, connected through the obvious catchwords of scheming (謀) and the greater good (大).

Guōdiàn "Zīyī” unit 12:

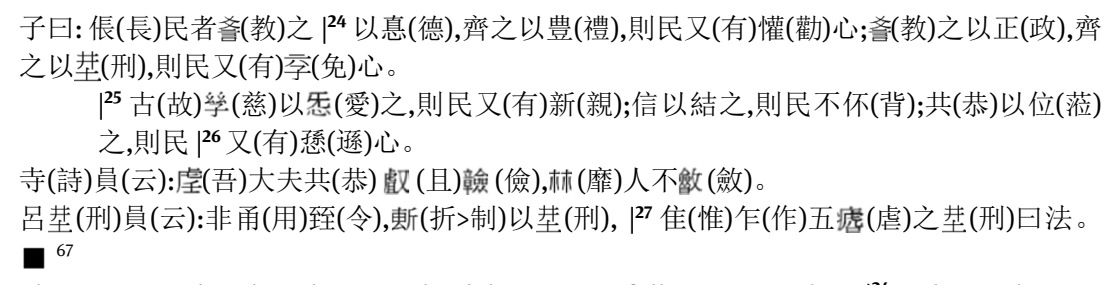

The Master said: 'When the one to lead the commonfolks instructs them $\left.\right|^{24}$ with moral power and corrects them with rituals, then the commonfolks will have a diligent mindset; when [he] instructs them with governance and corrects them with punishments, then the commonfolks will have an avoiding mindset'.

${ }^{25}$ This is why 'when showing love to them to [generate mutual] caring, then the commonfolks will have [a sense of] being intimate [to the leader]; when being trustworthy to bind them [together], then the commonfolks will not revolt [against the leader]; when showing respect in governing them, then the commonfolks $\left.\right|^{26}$ will have an obeying mindset'.

Songs say: 'When my officers are respectful and prudent, none of the members of the rén group will not be receptive'. ${ }^{68}$

ences stably correlate with the kinds of content. While that is so, passages such as this one suggest there is overlap between these traditions before the texts become channelled in these two miscellanies. Grebnev admits this by noting that "Lü xíng" of the Shàngshū contains some $Y \hat{\imath}$ Zhōushū patterns while Liù tāo 六晴舀 (Six Bow-Carrying Cases) closely follows the framing patterns common in the kingly consultations of the Yì Zhôushū.

67 Guōdiàn "Zīyī" unit 12 (Lǔji 3): Slips 23/17-27/8. For the reconstruction of the text, see Shaughnessy 2006: 108-109; S. Cook 2012: 399-402.

68 The ode referenced here is not in the transmitted Shijing and it is also not referenced in the Lìji “Zìyì”. 
Lü’s punishments (呂刑) say: 'it is not that they (the Miáo?)] used commands; they regulated [the commonfolks] through punishments. ${ }^{27}$ Creating the punishments of the five mutilations, [they] called it law'.

This passage refers to “Lü xíng” 呂刑, consistently called “Fǔ xíng” 甫刑 in the Lǐji recension. Shànghăi has 呂型. ${ }^{69}$ It is a mere graphic variation from Guōdiàn and thus unproblematic.

Shànghăi qualifies the subject to the sentence 非角(用)臸(令) as 戝>㲘 (máo 現) (mªw-s) mín 民 (14/13-14). So too does the Lijì recension, which has miáo mín 苗( $\left.{ }^{\star} \mathrm{m}(\mathrm{r}) \mathrm{aw}\right)$ 民 'Miáo folks'. The two are phonetically stable and the difference can be ignored. The Lǐji recension is here identical with the Shàngshū in saying 苗民弗用靈, 制以刑, 惟作五虐之刑曰法 (among the commonfolks of Miáo, they did not use the power of goodness, but the restraint of punishments. They made the five punishments engines of oppression, calling them the laws). ${ }^{70}$ Guōdiàn does not specify the subject. Since the slips are complete this has nothing to do with material loss and must be explained differently. It may reflect a different set of ideas underlying the Shànghăi text; or the text communities around the Guōdiàn text saw no need to specify the subject. ${ }^{71}$

The negation differs slightly among the different recensions. ${ }^{72}$ Other changes mostly reflect typical features of instability in manuscript cultures. ${ }^{73}$ The Lijì recension continues the phrase in question further, but that has no bearing on Shū either. It does, however, cast light on the textual condition of the transmitted "Zīyī" as against the manuscript recensions of the text.

Altogether, the Shū are for the most part stably reproduced in the two transmitted recensions. There are, however, discrepancies between the transmitted

69 Slip 14/10-11.

70 The translation here follows Legge 1960: 591.

71 Because neither manuscript was produced in direct consultation of the other, the often cited 'slip of the eye' does not apply.

72 It is identical in the two manuscript texts. Liji has fěi 匪 ( ${ }^{\star}$ pəj), a mere graphical variation and fully stable phonetically. The Shàngshū negation has fú 弗 ( $\left.{ }^{\star} \mathrm{p}[\mathrm{u}] \mathrm{t}\right)$. While the two have broadly the same meaning, the change between the Shàngshü and the other three recensions is not graphical or phonetic.

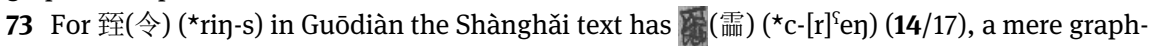
ical variant of 零 $\left.\left.^{*}[r]\right]^{i} i \eta\right)$ and probably phonetically compatible with Guōdiàn. The Lijì recension has ming 命 (*m-rin-s) which phonetically is fully congruent with the manuscript texts. The

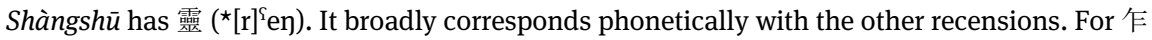
(作) in Guōdiàn the Shànghăi text has 复(作), a minor graphical variation that can be ignored. For nù̃e 虐 in the Lĭji and Shàngshū, the two manuscript texts each add a different signific, which has no bearing on the stability of the text. 
texts on the one hand, and the manuscript texts on the other, as well as between the manuscript texts, indicating that Guōdiàn and Shànghǎi were each distinctive interpretations, as were the received texts.

The "Zìy”" of the manuscript texts is organised around the theme of leading the people by embodying a model of cultural refinement, not punitive measures. The master saying contains both these aspects, but the Shì and Shū each contain just one of the two. Shì considers the notion of the cultural model. Shū considers the theme of punitive governance.

As seen before, the authorial voice of the "Zīyī" binds the three resources$z \grave{i}, \mathrm{Sh} \overline{1}, \mathrm{Sh} \overline{\mathrm{u}}$-together into one unit. More obviously perhaps than in the previous instances, it does so by way of a principal insertion ${ }^{74}$ that in a double-directed manner points upwards (to the $z \grave{\imath}$-phrase), as well as downwards (the Shī and Shū phrases). But again, thinking of it as contextualising any of the three resources might be going a step too far. Rather it seems to function as an intellectual bridge that eases the combined use of the three items of cultural capital.

Guōdiàn "Zìyī” unit 13:

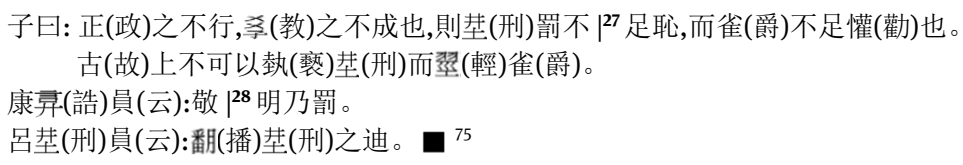

The Master said: 'It is when governance is not carried out [properly] and instructions are not completed, punishments and penalties do not ${ }^{27}$ suffice to shame [the people], and rank does not suffice to encourage [them]'.

This is why 'those on top cannot take punishments as [mere] garment and consider rank lightly'.

Proclamation concerning Kang (康誥) say: 'make reverent $\left.\right|^{28}$ and brilliant your penalties'. Lü’s punishments (呂刑) say: 'sow the lead through punishments'.

The theme connects well to the one of the previous unit by producing master sayings and Shū phrases, combined by the text's authorial voice, which together dwell on the ways punishments and penalties ought to be carried out in governance. Nonetheless, it differs from the majority of "Zīyì" units in that it leaves out the Shì and istead uses the Shū traditions twice. Interestingly, all four recensions,

74 A 'principal insertion' is a structurally alien element cutting through an otherwise consistent unit. (Here it is the sole element of authorial voice placed between the cultural resources of $z \grave{\text {, }}$ Shì, and Shū.) In argument-based texts it normally formulates the main idea of unit of thought. For a discussion, see Meyer 2011.

75 Guōdiàn "Zìyī” unit 13 (Lǐji 13): Slips 27/9-29/10. For the reconstruction of the text, see Shaughnessy 2006: 110; S. Cook 2012: 402-403. 
Guōdiàn, Shànghăi, Lǐjì and Shàngshū, are entirely stable in their use of "Kàng gào”. The phrase from “Lü xíng”, produced as 翻(播)芏(刑)之迪 in Guōdiàn, presents some instability, though mostly minor. ${ }^{76}$ Moreover, "Lü xíng" has the phrase 非時伯夷播刑之迪 (is it not the one, Bóyí, sowing [among the people] [his lessons of] leading through punishments), while Liji produces 播刑之不迪 (sowing [among the people?] [his lessons? of] avoiding punishments). No matter whether the difference in the Lijì recension responds to a different set of understanding or to a-later canonised-mistake, it shows how different text communities understood the text differently.

Guōdiàn "Zīyî̀" unit 17:

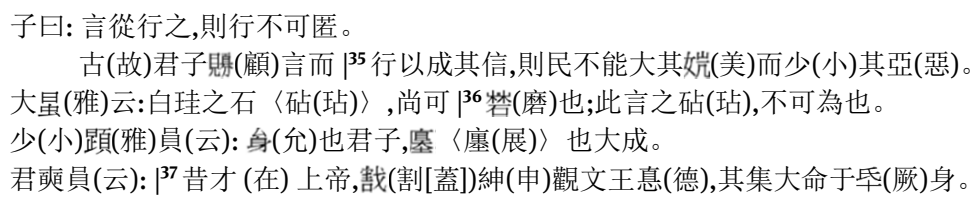

The Master said: 'when words are followed up by enacting them then actions connot be concealed'.

This is why 'when the Lord gives his testamentary decree and $\left.\right|^{35}$ enacts [it] to accomplish his trustworthiness, then the commonfolks are unable to exaggerate his beauty and hide his failings'.

"Dà yá" say: 'stones <flaws> in a sceptre of white [jade] may still be ${ }^{36}$ ground [away]; [but] for such flaw in speech, nothing can be done'.

"Xiăo yá" say: 'faithful is the Lord, in laying out [his] great achievements'.

Lord Shi (君奇) said: ${ }^{37}$ 'in days yore, the Lord on High surely stretched out to observe King Wen's charismatic power and thus gathered the great Mandate on his [own] person'.

This unit incorporates a master saying, authorial voice, lines from the Songs of the "Greater"- and "Smaller Elegantia”, and speech ascribed to Lord Shi (Jūn Shì). The latter is also the name of a chapter in the Hàn-era Shàngshū. The Lord's speech is produced in an identical manner in the Shànghăi manuscript text, as well as in the received Liji.

Unfortunately the tail of Shànghăi slip 18 is broken and the first eleven or so graphs are missing in that unit. It is therefore not possible to compare the two

76 Shànghăi has 宩 (15/22) for 翻(播), but it looks as though this graph is phonetically stable because 采, which might be the phonophore, is the same in both graphs. The same is true for di 迪 ( ${ }^{\star} l^{\complement}$ iwk) 'to lead' which has only the phonophore in the Shànghăi text. Lǐji also has bò 播 ( $\left.{ }^{\star} \mathrm{p}^{\mathrm{S}} \mathrm{ar}-\mathrm{s}\right)$ 'to sow' but the remaining bit differs between the manuscript recensions on the one hand and the received ones on the other.

77 Guōdiàn "Zīyī" unit 17 (Lǐjì 23): Slips 34/8-37/17. For the reconstruction of the text, see Shaughnessy 2006: 114-115; S. Cook 2012: 408-409. 
manuscript recensions more fully. ${ }^{78}$ The speech is rendered stably in all four recensions, Guōdiàn, Shànghăi, Lǐjì and Shàngshū. They do, however, differ in their references.

In Guōdiàn (and given their overall stability, most likely Shànghăi too), ${ }^{79}$ as well as in Lǔjì, Jūn Shì as a resource is used as though it was the speaker of the oration. In the Shàngshū, however, he is the addressee. The Shàngshū has the following line:

\section{君通！在昔上帝割申勸寧王之德, 其集大命于厥躬}

Prince Shi! In days of yore when the Lord on High was inflicting calamity [on Yĩn], he repeatedly encouraged the charismatic power of King Ning, thus gathering the great mandate on his [own].

Parallel to the other occurrences in "Zīyī" where Shū speeches are rendered stably, but their references differ among the text recensions, here too we have the situation where a stable speech component takes different contexts. The Liji recension differs yet again. As in the manuscript texts the subject is the Lord on High. But it is he who in the 'fields of Zhōu observe(s) King Wen's charismatic power' (周田觀文王之德). Again, what we see from this is how different conceptual communities produce an altered understanding of a fabula with its stable core constituents.

That words and deeds of a ruler must correspond to prove his faithfulness is the unifying theme of this unit. However, the texts do not seem to present this as an end in itself. The different resources all take it as a means to secure power over a political entity - if indeed one considers it viable to contextualise Shi in this unit accordingly. The phrase attributed to Lord Shi is much clearer in this regard.

Guōdiàn “Zīyī” unit 18:

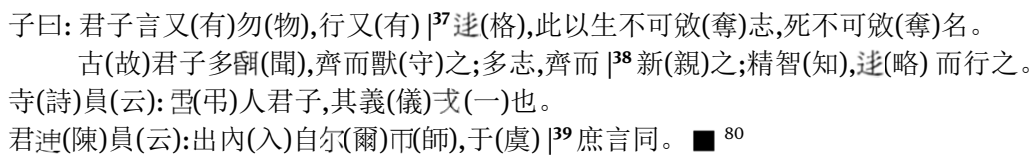

The Master said: 'when the words of the gentleman have substance (are concretely followed by things) and [his] actions are of ${ }^{37}$ regularity [force], then it is such that while [he] is alive

78 The remaining six graphs of that phrase are identical in the two texts, except that Shànghăi has 6 (氏) (19/5) where Guōdiàn has そ> 羊(厥) (37/16). This is, however, a mere graphical variation as the phonophore is identical in both graphs. This is a typical change in manuscript cultures with no bearing on the stability of the text.

79 Shànghăi equally starts off by 'Jūn Shì said'. (Remaining graphs of Slip 18.)

80 Guōdiàn "Zìyī" unit 18 (Ľiji 18): Slips 37/18-40/3. For the reconstruction of the text, see Shaughnessy 2006: 115-116; S. Cook 2012: 410-411. 
[his] wishes cannot be robbed [from him], and when [he] is dead [his good] name cannot be robbed [from him]'.

This is why 'a gentleman has many [things] into which he enquires, and evenly [he] safeguards them. [His] wishes are many, and evenly [he] $\left.\right|^{38}$ holds them dear. [He] has refined understanding [of the things], and in a regulated way he acts on them'.

Songs say: 'the good and noble person, their standards are $\left.\right|^{5}$ uniform'.

Lord Chen (君陳) said: 'in coming or going, when you [take] from your captaincies, anxiously [consider] whether [your] words ${ }^{39}$ comply with the multitudes'.

Unit 18 is the last of the manuscript texts that incorporates Shū. It relates to speech by Lord Chen. A text of that name, “Jūn Chén” 君陳, is part of the pseudoKǒng Shàngshū.

The recensions that refer explicitly to "Jūn Chén" (Guōdiàn, Shànghăi, Liji) do so in identical ways. The reproduced text too is stable for the most part. ${ }^{81}$

The received "Jūn Chén" differs though. As in the previous cases, in the received text Lord Chen is not the resource (speaker) but the addressee, thus indicating a marked interruption in the contextualisation of the materials by the participating text communities. Moreover, in the received text the referenced line reads as follows:

\section{出入自爾師虞, 庶言同則繹}

Whether you take out or bring in [something], seek the judgment of the multitudes about [it], and, when there is general agreement, exert your own powers of reflection.

While this reading follows the conceptualisation of the phrase by the Eastern Hàn commentator Zhèng Xuán 鄭玄 (AD 127-200), it is clear that it differs substantially from other recensions. Unit 18 thus confirms the picture of Shū as a resource adapted to different contexts by dynamic communities.

81 The manuscript texts have chūnèi 出內 for 'coming and going' while the Lĭ̉i has chūrù 出入, a mere graphical difference, as the phonophore of the graphs remains the same. That is true

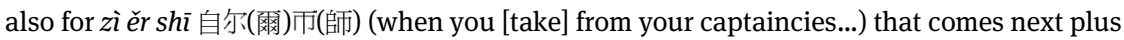
yú shù yán tó 于(虞)庶言同 (anxiously [consider] whether [your] words comply with the multitudes). While some graphical differences occur, the phonophore of these graphs remains notably stable, and so too the phonetical value of these graphs. One difference might apply to graph 39/27₹>yú 于 $\left({ }^{\star} \mathrm{G}^{\mathrm{w}}(\mathrm{r}) \mathrm{a}\right)$, written as $>$ 雮(于) (20/16) in Shànghăi. The Lĭjì recension has yú 虞 $\left.\left({ }^{\star}[n]\right]^{\mathrm{w}}(\mathrm{r}) \mathrm{a}\right)$ 'anxiety'. As they have the same phonetical value, we may read them here as standing in for the same word too. The manuscript recensions are therefore remarkably stable with the received $L$ riji with regard to this one line. 


\subsection{Conclusion}

The picture that emerges from the comparison of intertextual correspondences is one of surprising textual stability. It is surprising insofar as the various texts studied in this chapter represent independent recensions, making it unlikely that they either shared the same Vorlage, or that they were produced from one another. It is therefore not suprising to see that, despite some significant text overlap, there are several important differences between them. These are twofold structurally. First is the lexicon of the referenced passages: while in some cases the Shu as reproduced in the recensions displays stability of the content, the lexicon nonetheless differs. This may be graphically, phonetically, or both at once. Because this phenomenon is symptomatic of manuscript cultures it has no profound bearing on our evaluation of the Shù.

The other structural difference is the conceptualisation of Shū passages by the different text communities: while key text elements remain remarkably stable in the different recensions, the story they render can nonetheless differ substantially. What is striking is the extent to which the Shū differ from the Shì in this regard. The text condition of Shì in manuscript texts, we recall, is characterised by a volatile lexicon within a surprisingly steady phonetic setting. While this points to a profoundly oral factor in the reproduction-and reinterpretation-of Songs, it also casts light on their stable textual condition. ${ }^{82}$

That is not true of Shū as seen through "Zìyì" and related texts. Here we understand that both the lexicon and the presentation of the stories can differ, sometimes substantially, between the different (re-)productions of Shū, even though its key text constituents, in particular speech, remain recognisably steady. The emerging picture is that small but stable 'speech components', as I call them, were paired with other, again modular, components. The speech components look as though they belong to a recognised pool of cultural capital, used variously in the different recensions. Moreover, while the Shi maintain their strongly oral aspect, $S h \bar{u}$, it seems, depended more on written representation.

In the light of these findings, some points relating to the Shū, as well as to the way they are presented in "Zīyì", are worth discussing in more detail. First, in the various text traditions there is a notable instability of the triangular relation of Shū speech components, their orators, as well as their projected recipients. ${ }^{83}$

82 This point does not contradict that, as seen from Ān Dà Shī, some literate communities filled the productive mould of Shì by speaking through writing in their reproduction, and claim, of the Songs.

83 This point was first made in Meyer 2014c. 
The manuscript texts of "Zìyī" often introduce the speech components by the name of a speaker, while in the received counterparts they are not registered as speakers but as addressees of the speech. I cite unit 17 of the manuscript texts as an example. ${ }^{84}$ Here "Zīyī" reads as follows:

君奤員(云): ${ }^{37}$ 昔才 (在)上帝,䟠(割[蓋])紳(申)觀文王惪(德),其集大命于氐(厥)身。

Lord Shi said: ${ }^{37}$ 'in days yore, the Lord on High surely stretched out to observe King Wen's charismatic power and thus gathered the great mandate on his [own] person' ${ }^{85}$

In the Shàngshū, however, Lord Shi is not the speaker but the recipient:

君奤！在昔上帝割申勸寧王之德, 其集大命于厥躬。

'Lord Shi! In days of yore when the Lord on High was inflicting calamity [on Yin], he repeatedly encouraged the charismatic power of King Ning, thus gathering the great mandate on his [own]' ${ }^{86}$

This is a different thing. It yields two alternative but mutually exclusive explanations. One, "Zīyī" refers not to the speaker Lord Shi but to a text of that name. That would mean we should not read it as 'Lord Shi said' but as 'in "Lord Shi" it is said'. Alternatively, at the time when "Zìyī" was formed, the speech was in the first instance associated with the persona of antiquity (Lord Shi), not a text of that name. ${ }^{87}$ This assumption implies that the speech had been kept-in whatever ways-as part of the repertoire of cultural learning and rendered accessible and reproduceable to different audiences. The given identification then hardened in the received "Zīyī", but it did not continue into Shū traditions as produced in the Shàngshū.

This is not a far-fetched assumption. Consider the constitution of "Zīyī" in comparison to the texts referred to in it. "Zīyì" has produced a much greater stability of its own then the texts interwoven with it. Rather than by its focal reference to Shī and Shū, text stability in "Zīyì" was achieved predominantly through its tightly-knit frame and the brief lines as used in the fairly concise units of thought. "Zīyī", it would seem, has thus produced a mould that was continued in

84 Guōdiàn "Zīyī” unit 17 (Ľìi 23): Slips 34/8-37/17.

85 Guōdiàn "Zīyī” Slips 36/22-37/17.

86 Shàngshū jiào shìyì lùn, vol. 3: 1573.

87 The implicit consequence of this assumption is that the contextualising elements such as frames that place such utterances within a particular setting were added at a later point to make those speeches meaningful in the sociopolitical debate of changing text communities. 
other recensions where the identification of the orator with that speech is stabilised. But that identification was not maintained in the recensions further removed from "Zìyi”".

If the above assumption holds, it provides a viable explanation as to why a text such as "Zïyi" was produced in the first place. The question arises because "Zìyi" is so squarely at odds with much else from that time. While the texts of, say, "Lăozi”"-or, more accurately, those texts that are commonly associated with the tradition of that name ${ }^{88}$-are partly also context-dependent and produced in largely disconnected units of thought, "^Lǎož”" nonetheless contains neat argumentative layers, largely absent in "Zīyì". Unlike most known texts, "Zìyì” in the first instance presents just master sayings, paired with phrases from the Shi and Shū.$^{89}$ In the great majority of cases they are held together by a further, authorial, voice. Introduced near-consistently as 'this is why' (gù) it functions as a principal insertion which, in a double-directed manner, relates the three resources thematically to one another - unless of course we take this voice as part of the master saying (zi), in which case the units lose their organising, thematic focus. While the authorial voice structures the various units of "Zīyì" thematically, it does not produce an obvious argumentative structure. In some cases, the connection between the three resources within the various units of thought is also not entirely obvious, despite the structuring authorial voice, as the following unit shows:

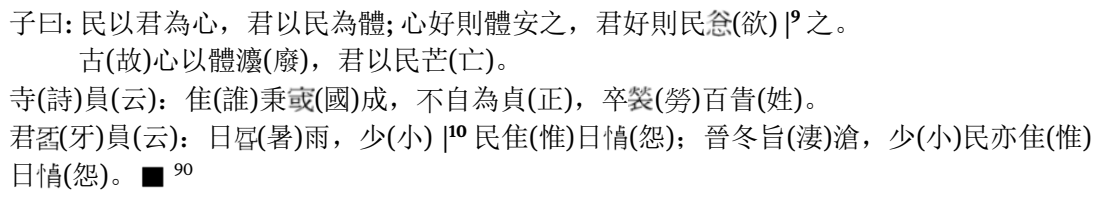

The commonfolks take the lord as their heart, the lord takes the commonfolks as his body; when the heart is good then the body will find comfort in it, and when the lord is good the commonfolks will desire $\left.\right|^{9} \mathrm{him}$.

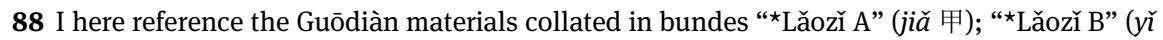
乙); “夫Lǎož C” (bǐng 甲丙), which so far present the earliest extant overlap with the transmitted text of that name. But, as William Boltz remarked so astutely, we should beware of labelling a late fourth-century $\mathrm{BC}$ manuscript 'with a name, for which our first evidence is a century or more later'. (Boltz 1999: 596)

89 Given that "Zìyì" is on the whole contructed around authoritative statements, it seems likely that the master sayings were already conceptualised as coming from the master as the persona of philosophical insight (viz. Confucius) as imagined by certain communities at quite an early moment in time.

90 Guōdiàn "Zīyī” unit 5 (Lǐji 17): Slips 8/7-10/14. For the reconstruction of the text, see Shaughnessy 2006: 100-101; S. Cook 2012: 384-386. 
Songs say:

This is why [it is said] the heart is laid waste by the body and the lord may disappear on account of the commonfolks.

Whoever holds to the accomplishments of the state? Not serving as the standard himself, in the end he belabours the many surnames.

Lord Ya (君牙) said:

When summer rain comes daily - the petty $\left.\right|^{10}$ folks resent it more by the day; when the brisk cold of winter approaches - it is equally true that the petty folks resent it more by the day.

While obviously there is an associative link between the master saying and the text of Shì and Shū in that they can all be taken as comments on the effects a ruler's conduct has on the commonfolks' sentiments (and their conduct), made explicit through the authorial voice of this unit, there is no obvious argumentative link produced within that unit that would help to establish a necessary hierarchical interrelation of the different resources. Instead, the references are presented more in a co-ordinate fashion such that they remain on the same conceptual plane, or so it seems. Whether they feature co-ordinately to one another in a loosely associative way, and fitted in a given unit of thought within "Zīyì" through the authorial voice, they all have their relevant place in relation to given themes. In this manner, "Ziyì" has produced a matrix that allows its text communities to store common phrases associated with high antiquity and relevant for that meaning community as made explicit by the authorial voice - perhaps to protect them from the effacing effects of time. This also explains why the phrases embedded in "Zìyi" produce much greater stability within the texts of the different recensions, than their counterparts outside "Zīyì”. In this way "Zīyì” can serve as an archive for a meaning community to whom the cultural lore seemed vital: a storehouse of cultural capital, structured and organised thematically by the accompanying authorial voice, and made available to certain communities who may wish to capitalise on this repertoire of learning.

Second, besides the structuring authorial voice, the two manuscript texts of "Zīyì̄" are tightly organised around master sayings, Shī and Shū. The inclusion of material that is now included in the Yì Zhoushu shows that at least certain text communities would not draw a conceptual distinction between them. While there are now clear structural differences between the texts in the imperial Shàngshū and $Y \hat{i} Z h \bar{o} u s h \bar{u},{ }^{91}$ it is likely that they just reflect, unknown to us, the principles of later communities to organise Shū in different traditions. "Zīyì" therefore

91 See the discussion in Grebnev 2017. 
plainly shows that such contrasting conceptualisations were certainly not upheld across all the communities. ${ }^{92}$

Third, closely related to the previous two points, the extraordinary stability of "Zìyi" springs to mind. We noted that a limited range of textual features suggests that Guōdiàn and Shànghǎi were not copied from one another but relied on a third, independent Vorlage. Structurally the two versions are nonetheless near identical. This is remarkable as both texts include the same compositional inconsistencies. Of the units cited here, that is, the units which include a reference to the Shu traditions, just two-3 and 10-lack the authorial voice which normally highlights the thematic relation of the three resources of cultural capital, zì, Shī, and Shū. Moreover in unit 7 the authorial voice is not marked explicitly by way of

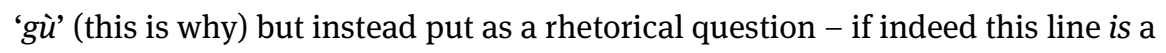
representative of the authorial voice. The fact that the two accidentally obtained and mutually independent manuscript texts of "Zīyī" both uphold the same structural departures from the overall compositional norm suggests a remarkable stability of this particular recension by the fourth century BC. This is further evidence, together with the closing number, twenty-three (èrshí yŏu sān二十又[有] 三) at the end of the Guōdiàn manuscript, that during the Warring States "Zīyì" was a stable text that circulated through multiple witnesses.

Fourth, "Zìyī" confirms the tripartite reference structure of 'master - Shī Shū' that was stabilising during the Warring States among certain communities. It shows that the master-the Master-was for some communities a cultural resource equal in rank to the foundational texts, Songs and Documents.

Fifth, as against Shī, "Zīyì” never refers to Shū in generic terms. Instead the point of reference is always to a particular text, or, for that matter, speaker. Shū are represented in their particularity while Shì constitute a group of their own. This is important as it reflects on the conceptualisation of these two traditions by the communities of the day. The whole situation becomes even more remarkable when one considers that references introduced as Shū yún 書云 or Shū yue 書曰 in the received literature from the pre-Hàn and Hàn dynasties number nearly a thousand, compared to not one single reference (!) of the kind in a manuscript text. $^{93}$

92 These findings correspond broadly with Lǐ Xuéqín's (2010) take on the Yì Zhōushū. Lǐ contends that as late as the Warring States there was probably no distinction between the Shàngshū and the Yì Zhōushū. He suggests that the Yì Zhōushū did not come to be considered an independent text until the Hàn period.

93 The Xúnzǐ alone has ten times the line 'Shū say' 書曰, as does the Mèngzǐ. 'Shū say' 書云 references are found predominantly in texts from the former and latter Hàn. Shuǐhǔdì 1990: 148, “Fēng zhěn shi” 封診式 4 has the line: 詰之極而數訑, 更言不服, 其律當治（笞）諒（掠）者, 
This is extraordinary, casting light on two parallel phenomena. First: the shift that we see materialised in the transmitted literature where the notions from the texts of Shū traditions are rendered generically as 'in a shū it is said'-and not as particular texts or individual orators-presents a markedly transformed understanding of Shū traditions during the imperial age. Second: that shift which we see materialised in the transmitted texts (note that the transmitted texts were to some degree all amended during the imperial age) is conceptually identical-and therefore parallel to and thus highly instructive-with the shift seen in the manuscript texts, where Shī are conceptualised in generic terms while Shū are taken as particular texts or individual orators. Nota bene, as manifested in "Zìyī”, it becomes plain that the conceptual differences just described were being upheld by mutually overlapping text communities.

This striking difference between Shī and Shū is clear not just from the referencing formulae. It is also evident from the relatively sparse references to Shū in manuscript texts as compared to Shì. How does this look in larger cultural developments?

In a number of essays, Reinhart Koselleck coined the term 'threshold period', Sattelzeit (literally 'saddle period'), to describe an epoch where key concepts and guiding terms experience conceptual transformation. Prime denotations become reformulated and change their meaning. Koselleck devised the threshold period in reference to conceptual developments in the sociopolitical terminology between the years 1750 and $1850 .{ }^{94}$ At the time, common terminology is submitted to an increased abstraction while key notions undergo fundamental singularisation and, with it, profound change. One example is past experience. As Koselleck proposes, it shifted from experienced episodes, understood in their particularity

乃治 (答) 諒 (掠)。治 (笞) 諒 (掠) 之必書曰: 爱書: 以某數更言, 冊 (無) 解辭治 (笞) 訊某 which has: 'When one has cross-examined to the limit, but he has repeatedly lied, changing his words and not submitting [to the denunciation against him], then, for those persons whom the statutes say match being caned, cane them. When caning him, be sure to write it down. Received in writing: Because person $\mathrm{X}$ repeatedly changed his words and made no explanatory statements, person $\mathrm{X}$ has been interrogated with caning, which obviously just talks about the act of writing down a report. These observations do not conflict with the generic mention such as shī, shū, lǐ, yuè as seen from "Xìng zì mìng chū" or the like. (My translation of "Fēng zhěn shì" follows Barbieri-Low and Yates 2015: 156, adapted.)

94 See his Geschichtliche Grundbegriffe, vol. 1: xiv ff. (1972); vol. 2: 363 ff; 625 ff. (1975); 1979: 107; $349 \mathrm{f}$. 
and the singularity of each event (Geschichten), to its conceptualisation as 'history' (Geschichte) in the form of a collective singular. ${ }^{95}$ Connected to such shifts is the rise of a terminology as a horizon of expectations, which is sometimes quite remote from actual experience. Koselleck calls this phenomenon 'temporalisation' (Verzeitlichung). Such profound changes in the conceptual range of the sociopolitical terminology during the threshold period were ultimately triggered by the diffusion of knowledge through an increase of written texts in wider circulation and the opening of institutions to a wider public, previously restricted to small, highly privileged, parties.

This is not a unique phenomenon of the threshold period. The German ancient historian Christian Meier (born 1929) identifies the same patterns in the transformation of the conceptual range in the Greek world of the fifth century BC, equally profound and wide-ranging. To name but one example, he points to the formation of concepts such as 'eunomia' (Evंvopía) as the one right order, ordained by the gods, now understood as the ultimately valid sociopolitical condition of legal order. ${ }^{96}$ As is true of the threshold period, the shift towards the collective singular as the result of a changing conceptualisation of shared experience was equally prompted by the breakdown of restricted institutions as a result of the dispersal of knowledge.

Similar processes are at work in China during the second half of the first millennium BC. ${ }^{97}$ At that time, we observe profound changes in how groups conceptualise their immediate experience, owing to the wider accessability of knowledge as a result of ever more texts in written circulation now that manuscript cultures are maturing and stabilising. ${ }^{98}$ The conceptual shift in the term

95 Note that while Koselleck's enquiry into the transformation of the conceptual range has now been shown to be more complex (in Sawilla 2004), the implications of his findings remain - albeit that the answers to his questions prove somewhat more complex.

96 C. Meier 1980: 279.

97 This period is often referred to as 'axial age' (Achsenzeit). While the German philosopher Karl Jaspers (1883-1969) was not the first to conceptualise a key period in the history of thinking as 'Axial age', it was he who popularised it in Vom Ursprung und Ziel der Geschichte (1949).

98 These processes are discussed in more detail in Meyer 2011 and 2014b. As for what characterises the Axial Age, I follow Björn Wittrock's 2005a: 112 (and 2005b: 72) understanding, influenced, I think, by Koselleck, that the Axial Age is not defined by its reference to the transcendental but rather by 'an increasing reflexivity of human beings and their ability to overcome the bounds of a perceived inevitability of given conditions in temporal and social orderings'. The literature on the Axial Age is too vast to review it in full. See, however, the important discussions in Aleida Assmann 1989 and 1992; Shmuel Eisenstadt 1987, 1992, and 2008; Robert Bellah 2005 and 2011. Some of these articles have a very different take on the Axial Age as characterised by Wittrock. Bellah in particular takes a highly ‘Western’-centric, even Hegelian view by describing 
jūnž 君子 is a case in point. As analysed sharply by Vitali Rubin, it developed from meaning 'person of high social standing', to becoming 'person of moral integrity' - with criteria varying from text to text. ${ }^{99}$ Along with these changes, the descriptions of a jūnž changed too. Moving on from describing predominantly the outer appearance of the jūnzǐ as a handsome-mostly young-man and exemplary prince, the texts increasingly lay stress on his inner qualities. See the wellknown ode from the “Odes of Wèi” 衛風 (Máo 55):

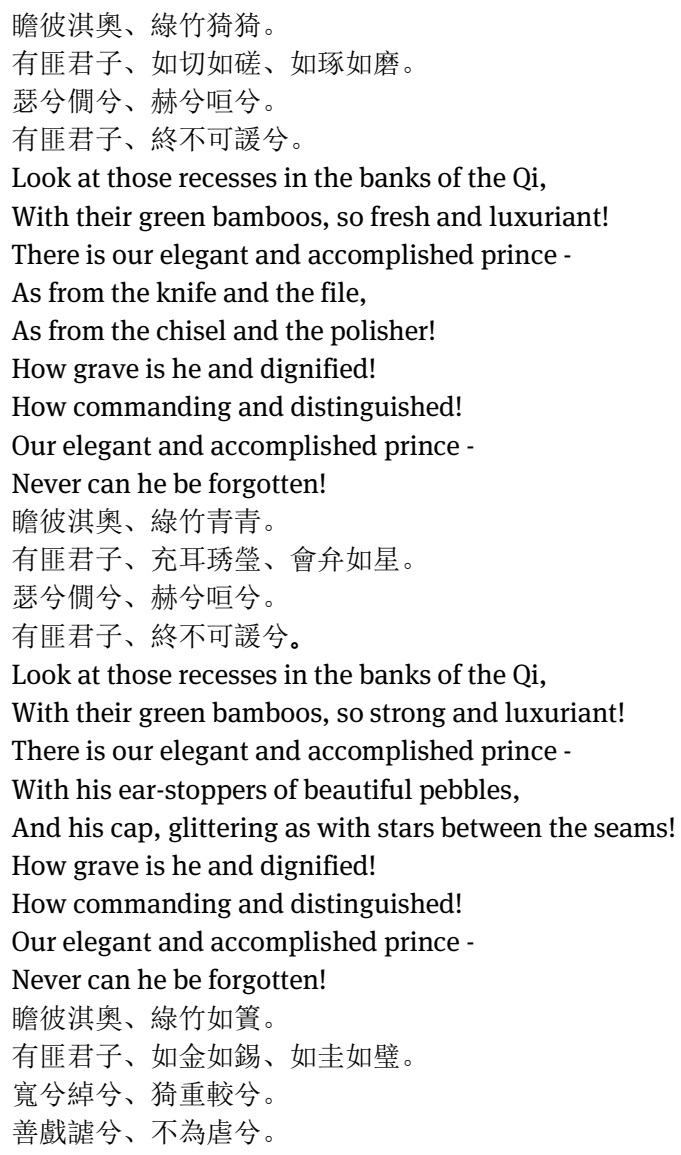

it as a series of stages reminiscent of Hegel's Bewusstseinsphilosophie (philosophy of consciousness).

99 Rubin 1976. Nota bene, the change as occurring during the second half of the first millennium BC is structurally parallel to that of 'gentleman' in the English context (Rubin 1976: 20) during the eighteenth century, the threshold period in Europe. 
Look at those recesses in the banks of the Qi, With their green bamboos, so dense together! There is our elegant and accomplished prince -

[Pure] as gold or as tin,

[Soft and rich] as a sceptre of jade!

How magnanimous is he and gentle!

There he is in his chariot with its two high sides!

Skilful is he at quips and jokes,

But how does he keep from rudeness in them! $!^{100}$

As ever more texts are beginning to describe the aristocratic, gentle jūnzi as a superior person with good judgements and high morals, he gets repeatedly contrasted with the xiăo rén 小人, the 'petty men'. This shift reaches its conclusion during the Warring States when the term becomes a stable concept in sociopolitical and philosophical discourse. ${ }^{101}$

The collective singular Shì for wider traditions of quite diverse songs that frame the experience of the learned elite and are the basis of the lingua franca in the sociopolitical language of the day is another marker of change. Its use referring to all kinds of odes (as in shī yún 詩云 or shī yue 詩曰) runs to nearly two thousand in the transmitted literature, and manuscript texts referring to that body of texts and in those terms abound too. But no bronze text ever uses this expression. My initial conclusion is that the Shi accelerated in the rate by which they were used in debate, so that they came to be seen as the pinnacle of refinement. As Shì become the ultimate expression of sincerity and appropriateness, they mark an idealised form of communication. But the groups' conceptualisation of Shì and their conceptualisation of Shū are out of step - and this may have to do with the main form of circulation and transmission of those texts. While Shi depend on rhythm and assonance to keep their integrity, they are much more easily learned and remembered, and so effortlessly used and reproduced.

Shū differ. They do not impress their audience with strict rhythm and smooth assonance. They are more unwieldy to use and reproduce. The result is that in comparison to Shī we see far fewer intertextual references using Shū, and a much

100 Legge 1961: 91-93. The date of composition of Máo 55 is open to question, but it is unlikely as old as the "Small Preface" suggests, that is, made before or during the early days of the reign of King Ping 平, r. 770-720 BC. Western Zhōu bronze texts which contain the term 'jūnzì all say ' $\mathrm{X}$ 君子 Y', which translates as ' $\mathrm{Y}$, the son of lord X'. The concept of 'handsome gentleman' for jūnzi therefore most likely postdates the Western Zhōu.

101 Note that the term wén 文 underwent a parallel shift to that of jūnž̌, from 'pattern', carrying the meaning of 'awe-inspiringly beautiful', to 'morally refined' during the Warring States. Bergeton 2019: 49ff. 
greater variation of those lines. There is therefore a delay in conceptualising them in any other form but their particularity. It thus took more time for Shū to be used as a collective singular, conjoining the expectations of various groups and serving as their primary source of identification. 